Portland State University

PDXScholar

1983

\title{
Polish foreign policy and the development of the Conference on Security and Cooperation in Europe
}

\author{
Keijiro Yasui \\ Portland State University
}

Follow this and additional works at: https://pdxscholar.library.pdx.edu/open_access_etds

Part of the Comparative and Foreign Law Commons, European Law Commons, and the Political Science Commons

Let us know how access to this document benefits you.

\section{Recommended Citation}

Yasui, Keijiro, "Polish foreign policy and the development of the Conference on Security and Cooperation in Europe" (1983). Dissertations and Theses. Paper 3329.

https://doi.org/10.15760/etd.3309

This Thesis is brought to you for free and open access. It has been accepted for inclusion in Dissertations and Theses by an authorized administrator of PDXScholar. Please contact us if we can make this document more accessible: pdxscholar@pdx.edu. 
AN ABSTRACT OF THE THESIS OF Keijiro Yasui for the Master of Arts in Political Science presented December 28, 1983.

Title: Polish Foreign Policy and the Development of the Conference on Security and Cooperation in Europe.

APPROVED BY MEMBERS OF THE THESIS COMMITTEE:
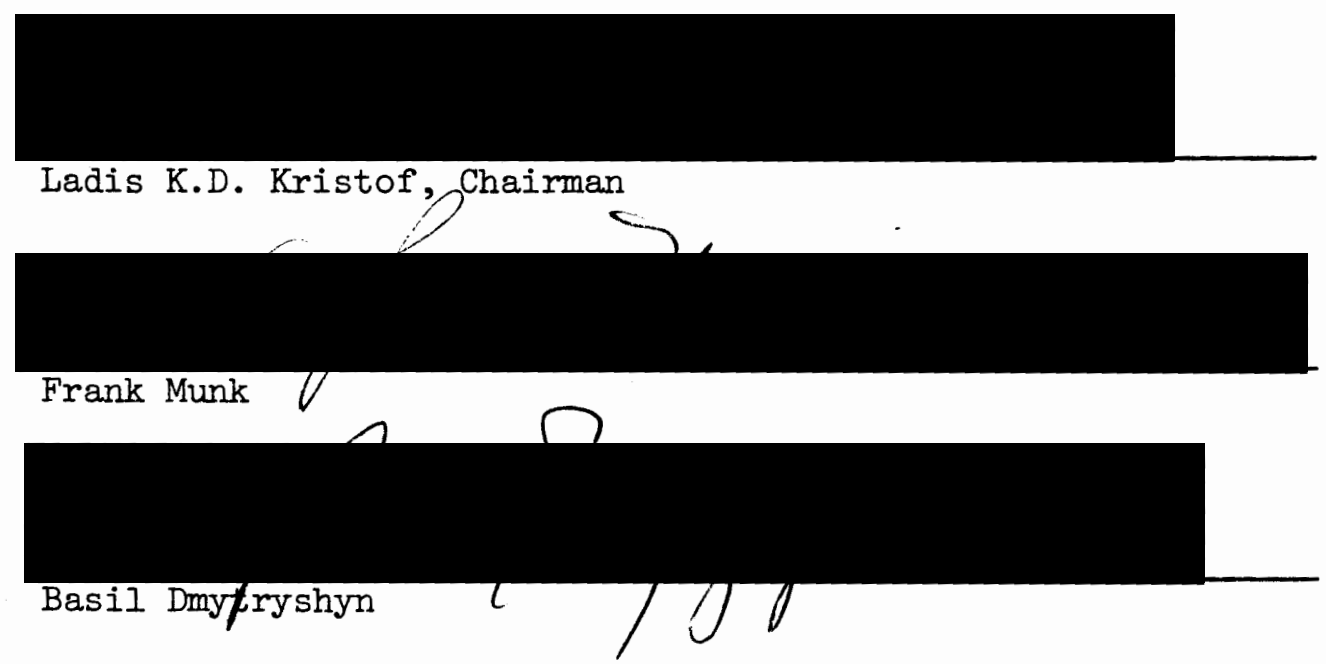

This thesis concerns the connection between the development of Polish foreign policy and the evolution of the Warsaw Pact's proposals for an allEuropean Conference on Security and Cooperation in Europe (CSCE). The first concrete CSCE proposal was put forward by Poland in 1964 . It reflected the Soviet Union's interests as well as those of Poland's.

The proposals were closely related to the situation which World War II had created for Poland. During the war Poland was massacred by both the Germans and the Soviets. It lost almost half of its territory to the Soviet Union 
and was moved to the West. Therefore, immediately after the war one could speak very little of Polish foreign policy. HOwever, since 1955 when West Germany was recognized by the Western Powers as a sovereign state and was rearmed, Polish foreign policy was greatly reactivated. This was precisely because a strong German state would challenge Poland's western frontier, which it had received as compensation for the land it had lost in the East.

Through various Rapacki plans and its vigorous campaigns for the Council on Security and Cooperation in Europe (CSCE), Poland attempted to prevent the emergence of a powerful German state, thus securing the finality of its western border. But these policies also aimed at decreasing the Soviet overlordship of Poland. With its vital territorial question settled and the Soviet influence over it decreased, Poland hoped to cultivate closer ties with Western Europe, from which it had been artifically separated. 
POLISH FOREIGN POLICY AND THE DEVELOPMENT OF THE CONFERENCE ON SECURITY AND COOPERATION IN EUROPE

by

KEIJIRO YASUI

A thesis submitted in partial fulfilment of the requirements for the degree of

MASTER OF ARTS

in

POLITICAL SCIENCE

Portland State University

1983 
TO THE OFFICE OF GRADUATE STUDIES AND RESEARCH:

The member of the Committee approve the thesis of Keijiro Yasui presented on December 28, 1983.

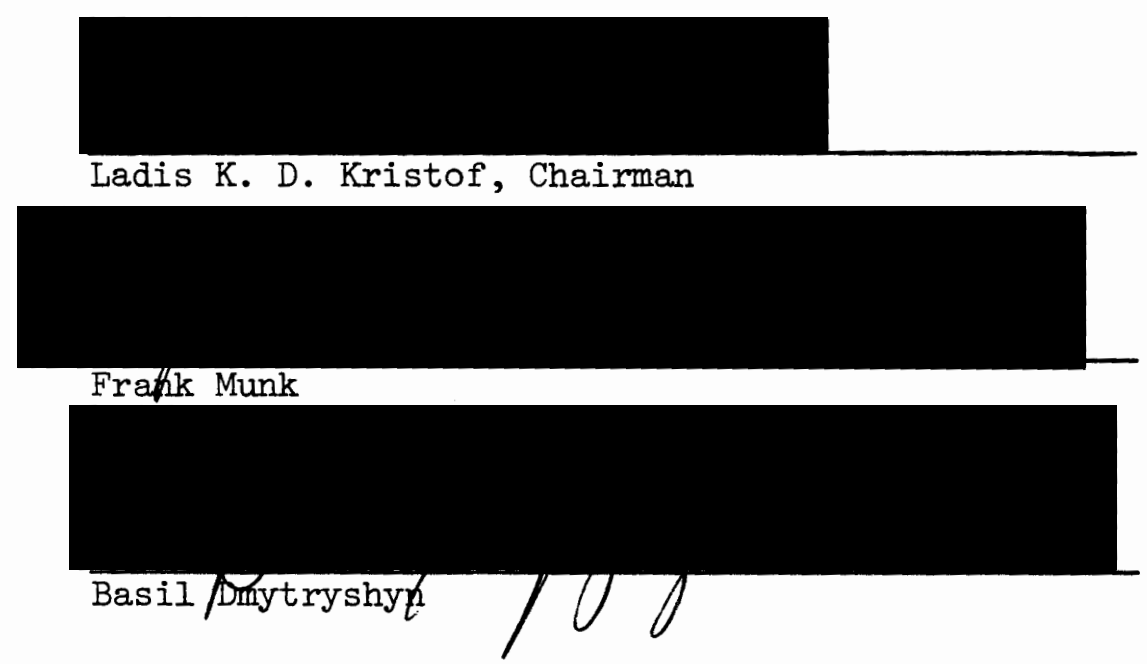

APPROVED:

David A. Smeltzer, Head, Department of Political Science 
PREFACE

This thesis concerns the connection between the development of Polish foreign policy and the evolution of the Warsaw Pact's proposals for an all-European Conference on Security and Cooperation in Europe (CSCE). The CSCE proposals reflected the Soviet Union's interests as well as those of Poland's. Some writers tend to identify the latter with the former, taking it for granted that Poland is merely one of the Soviets' "satellites", "proxies", or "client states". This oversimplification is misleading in light of the existence of genuine Polish interests which are perfectly consistent with Poland's history. However, it is also misleading to view these Polish interests as something independent of the overall political environment. The environment sometimes dominates the will of the people, but the process is always accompanied by initiatives to improve the existing environment. In this sense, the Soviet Union is no exception. The Soviets, too, interact with and work on the political environment so that it will change in their favor.

During W. W. II, Poland was devastated and its people massacred by both the Germans and the Soviets. It lost almost half of its territory to the Soviet Union and was moved toward the West. Therefore, immediately after the war one could speak very little of Polish foreign policy. Domestic politics were under the Russian overlordship, but occupied Germany posed no threat to Poland. This was a peculiar 
historical setting for Poland. However, the Poles soon found themselves in a familiar environment. In 1955, West Germany was recognized by the Western Powers as a sovereign state and was rearmed. It followed that this new German entity challenged Polend'is iwestern territories, which it received as a compensation for the land lost in the East. Polarid found itself again squeezed between Germany and the USSR.

It was in this circumstance that the Poles found themselves in need of their own foreign policy, and by this time the damage they had suffered from the war had begun to heal. Thus, the Rapacki Plan should be viewed as a Polish struggle to regain national independence, not overnight but gradually based on existing reality. The plan was a Polish initiative to improve the political environment step by step. The tension in Central Europe and the emergence of a powerful Germany, were obviously detrimental for the Poles' desire for greater autonomy. The former severely restricted Poland's room for maneuvering and the latter posed a danger for its vital western boundary. Furthermore, both of them would aggravate Poland's isolation from the West with which the Poles had shared for centuries their history, culture and basic values. After all, Poland was forcibly separated from Western Europe only in 1945. If allowed, it would again throw its fate with that of the West.

The holding of an all-European Conference on Security and Cooperation in Europe was to give Poland a precious gift. The acceptance by the West of postwar reality would not only alleviate the tension between the two blocs but also secure Poland's western 
frontier. Moreover, it was hoped that it would to a limited extent undermine the rigidity within the Eastern bloc. Thus, Polish foreign policy consistently followed the genuine Polish interest in its interaction with both the East and West. 
TABLE OF CONTENTS

PAGE

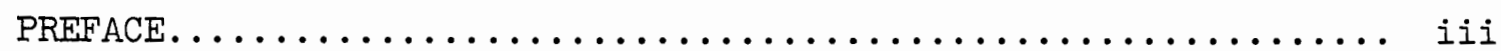
CHAPTER

I THE RAPACKI PLAN AND ITS VARIANTS..................

Notes for Chapter I...........................

II POLISH FOREIGN POLICY AND THE PROPOSALS FOR THE CONFERENCE ON SECURITY AND COOPERATION IN EUROPE........32

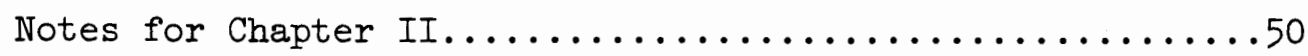

III POLISH-WEST GERMAN REIATIONS -- A KEY TO THE CSCE?......59

Notes for Chapter III $\ldots \ldots \ldots \ldots \ldots \ldots \ldots \ldots \ldots \ldots \ldots \ldots \ldots$

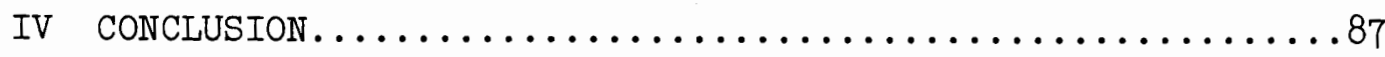

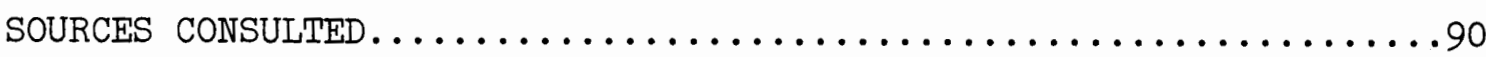




\section{CHAPTER I}

\section{THE RAPACKI PIAN AND ITS VARIANTS}

The holding of an all European Conference, as opposed to a greatpower meeting, was initially proposed by the Soviet Union in November 1954. However, already earlier in that year, it had proposed concluding an all-European treaty on collective security in Europe at the Berlin Conference of the foreign ministers of the United States, France, Britain and the Soviet Union. ${ }^{I}$ This proposal was rejected by the West primarily because it presumed East Germany's independent political status.

Between the Soviet proposal to conclude an all-European treaty on collective security in Europe in February 1954 and its proposal for an all-European Conference in November the same year, there was an important development in the West. In October, the Western powers signed the Paris Agreement that, among other things, admitted the Federal Republic of Germany to NATO." Faced with the realities, "the USSR, Poland, Czechoslovakia and the German Democratic Republic worked incessantly to prevent the ratification of the Paris Treaty. "3 The Soviet leaders emphasized the threat inherent in the Paris Agreement and accused the West of aggression. ${ }^{4}$ Thus, the initial proposal to hold an all-European Conference in November 1954 should be viewed as a part of the Soviet attempt to forestall West Germany's entry into the Western Alliance. 
Diplomatic efforts that were to prevent the rearmament of West Germany continued until the Paris Treaty was finally ratified in May 1955. Prior to the ratification of the treaty, the socialist countries had stated during a meeting in Moscow, "in the event of the ratification of the Paris Treaty we would be forced to establish closer cooperation and co-ordination of our armed forces in order to guarantee our security and preserve peace in Europe. " 5 When these threats and warnings proved unsuccessful, the Soviet Union, Poland, Czechoslovakia, the GDR, Hungary, Romania and Albania concluded the Treaty of Friendship, Cooperation and Mutual Assistance, called the Warsaw Treaty. The inclusion of West Germany into NATO thus preceded the establishment of the Warsaw Treaty Organization giving the socialist countries a strong rationale to accuse the West of initiating the division of Europe into hostile camps. 6

After the establishment of two opposing military blocs, the Soviet Union made diplomatic efforts to call for the simultaneous dissolution of them. ${ }^{7}$ In their attempts, they cited Article II of the Warsaw Treaty which read:

Should a system of collective security be established in Europe, and a General European Treaty of Collective Security concluded for this purpose, for which the Contracting Parties will unswervingly strive, the present Treaty shall cease to be operative from the day the General European Treaty enters into force.

This proposal was again based on the logic that by creating NATO and integrating West Germany into this military organization the West was responsible for the creation of the divided Europe. The corollary was that the who started first should quit first. However, the real 
motive behind the Soviet proposal was to disrupt the process of the military consolidation of NATO and of the West European plan for closer political and economic integration which required West German participation.

The Soviet proposal for the simultaneous dissolution of both military blocs faded away in 1958 when Nikita Khrushchev provoked a new crisis over Berlin and threatened to sign a peace treaty with the GDR alone. Thus, around 1958, the Soviet Union was not in the position to renew a call for an all-European Conference, even though it engaged in sporadic efforts in that direction and proposaed a nonaggression accord between the countries of the two military pacts that would have left both military organizations intact. 9 But these proposals were rejected by the West, since they implicitly placed East and West Germany on the same footing. ${ }^{10}$ The Soviet Union gradually moved toward a recognition of the rearmament of the FRG as a matter of fact and its proposal to convene an all-European Conference gradually disappeared.

The obvious failure of the socialist bloc to prevent the integration of the FRG into NATO affected Poland more than it did the Soviet Union. With no alternative Soviet plan left to secure its Western territory and to lessen the possibility of "West German Revanchism", the Polish leaders realized that the task was on their shoulders. As a result of these developments on the international scene, as well as of the Polish "October Revolution" in 1956, this period marked a turning point in Polish foreign policy in the sense that: 1) differences in foreign policy interests between the Soviet Union and Poland clearly 
began to emerge, 2) Polish diplomacy became very active, especially in Central Europe. In January, 1957, Chou Enlai visited Warsaw and in April, Jozef Cyrankiewicz and a strong Polish delegation visited China. Moreover, the visit by Mao Tse-Tung to Poland was planned. ${ }^{11}$ In September, 1957, Wladyslaw Gomulka initiated the idea of the neutralization of the Baltic region as a precondition for closer cooperation among the countries in that area. ${ }^{12}$ Furthermore, in the same month, Gomulka went to Belgrade, which was his first txip abroad since his return to power. His visit indicated the solidarity between Gomulka and Marshal Tito before and after the "October Revolution". During the visit Gomulka obtained Yugoslav recognition of the Oder-Neisse line as "the final frontier" between Poland and Germany. ${ }^{13}$ Gomulka also persuaded Tito to recognize the East German regime. ${ }^{14}$ During the same period, Poland asked for American economic aid in order to be less dependent economically on Soviet favor. Between June, 1957, and the summer of 1961, Poland received the aid which amounted to $\$ 365$ million. 15

On October 2, Polish Foreign Minister, Adam Rapacki, introduced his plan for denuclearization of Central Europe, later known as the "Rapacki Plan". It was during the general debate at the I2th United Nations General Assembly that Foreign Minister Rapacki declared:

Pending the establishment of a collective security system in Europe we shall give our support even to partial measures leading to this (denuclearization) goal.

Proceeding from the interests of Poland's security and detente in Europe and having coordinated its action with other member countries fo the Warsaw Treaty, the Government of the Polish People's Republic declares that if the two German states agree to prohibit the manufacture and stockpiling of nuclear weapons on their territory, the Polish 
People's Republic is prepared to extend such prohibition to its territory, too. 16

The plan was to include Czechoslovakia as well as both German states. The plan for a nuclear-free zone first appeared in the Spring of 1957 , in its tentative form in the periodical Swiat i Polska. ${ }^{17}$ At that time, it was to include not only the two German states, Poland and Czechoslovakia but also Hungary and Holland. ${ }^{18}$ At that point, the Soviet Union was rather indifferent to the idea. ${ }^{19}$ In Prague, the idea received a cool response, but it gained approval in Pankow. ${ }^{20}$ The East German leaders considered the plan an ingenious means by which their state and government might secure Western recognition, since they presumed that they would enter the scheme as an equal partner of West Germany. 21 It took a few months of persuasion in order to get the Soviet Union's support to take the first step. Czechoslovakia finally agreed to the Polish plan two months after Rapacki's speech at the U.N. 22

What was more important than the initiation itself of such a plan was the Polish rationale behind it. It was obvious that the heart of the tension was in Central Europe, more precisely in Germany. A relaxation of this tension was considered by the Polish leaders to be Poland's foremost interest at that time. However, since a global solution in the area was not conceivable at that moment, one could only begin to move forward stage by stage. Therefore, the Polish leaders decided to adopt a kind of political functionalism to lessen the tension in Central Europe, and then in Europe as a whole. Since major political 
solutions were impossible, a minimum of confidence had to be created by gradual disarmament. The logical conclusion was a voluntary ban on nuclear weapons in a defined area.

In December 1957 the Polish government repeated its proposal through diplomatic channels. In February 1958, in Warsaw, the Polish Foreign Minister delivered to the ambassadors of the concerned countries a memorandum containing detailed proposals on the establishment of a denuclearized zone in Central Europe. The text of the memorandum was also transmitted to the West German government with which Poland did not have diplomatic relations. ${ }^{23}$ The contents of the memorandum were as follows:

(I) The states of the nuclear-free zone (Poland, Czechoslovakia, and the two German states) pledge themselves not to manufacture, stockpile, introduce for their own needs or permit to be stationed on their territory any types of nuclear arms, and also not to deploy or allow on their territory any installations or equipment serving nuclear weapons.

(2) The four major powers pledge themselves not to arm their troops stationed on the territory of the states of the zone with nuclear weapons, and in no circumstances to hand over nuclear weapons to the governments or other authorities in these territories. The nuclear Powers must pledge themselves not to use these weapons either against the territory of the zone or against any objective on the territory.

(3) The states concerned undertake to establish a broad and effective control system on the territory of the proposed zone and 
submit to this control. 24

This memorandum was also the product of intense negotiations between the Poles, led by Rapacki, and the Soviet leaders. 25 The discussions focused on two issues: 1) the form of agreement that would enable Bonn to sign without having to negotiate with or enter into direct contractual obligations with Pankow, and 2) inclusion of conventional weapons in any agreements reached on nuclear-free zones. The first point became the center of negotiations precisely because of the Hallstein doctrine which was declared in late 1955, after Bonn and Moscow established diplomatic relations and because of Bonn's still maintained stand that the FRG represented the whole German state. Since September 1957, Bonn had applied the doctrine to Yugoslavia ${ }^{26}$ and had also refused to have any further contact with Poland, let alone with East Germany. On the second point, to leave conventional weapons in Central Europe intact meant to leave the Warsaw Pact's military superiority in that region also intact. With regard to this point, contention had been raised earlier by the West German Foreign Minister, Heinrich von Brentano even before the Rapacki memorandum was transmitted to him.

As a result of the negotiations, compromises were reached on these points. Concerning the first point, it was assented that the agreement would be based on unilateral declarations of the individual states. The text of the Memorandum read:

The most simple form of embodying the obligations of states included in the zone would be the conclusion of an appropriate international convention. However, to avoid the complications which some states might find in such a solution, it can be arranged that:

1. These obligations be embodied in the form of four unilateral declarations, bearing the character of an international obligation, deposited with a mutually agreed-upon depository state. 27 
In regard to the conventional forces, Rapacki had to concede in order to obtain the Soviet consent on the plan. Reduction of conventional weapons was excluded from the present Memorandum. It was only mentioned at the very end of the text:

The government of the Polish People's Republic has reasons for stating that aceptanee 0 f the proposal concerning the establishment of a denuclearized zone in central Europe will facilitate the reaching of an agreement relating to an adequate reduction of conventional armaments and of foreign armed forces stationed on the territory of the states included in the zone. 28

Without the inclusion of conventional forces, it was plain even to Rapacki that the plan would upset the military balance in Central Europe. Indeed, this point became the center of the Western objection to the Polish proposal in the months that followed. 29

Mainly because of these difficulties, the plan did not receive many positive replies. Nonetheless, it achieved limited diplomatic success. Poland demonstrated its sincere concern regarding lessening the tension in that part of the world. The leading Western states, far from ignoring the Warsaw Memorandum, sent friendly but basically negative replies. ${ }^{30}$ The notes sent by the American and Canadian governments in particular showed sympathy and appreciation for the Polish government's efforts. 31 However, the reaction of West Germany to the Polish proposal, which the Poles were more interested in, was very negative from the outset. Bonn did not even favor Poland with an Official reply. The Minister of National Defense, Franz Josef Strauss, denounced the plan as aiming at the weakening of the FRG, and questioned the wisdom of negotiating with Poland. ${ }^{32}$ Indeed, it was true that one 
of the objectives of the Rapacki plan was to prevent West Germany's nuclear armament.

The Polish fear of a rearmed Germany, let alone a unified Germany armed with nuclear weapons was understandable. The concern, shared by the Czechs, would even bring the communists and the nationalists closer together. The apprehension was based on the prospect that a strong Germany would seek to alter the still fragile Polish frontier, which was a matter of life and death to the Poles. Poland lost almost half of its territory to the Soviet Union, and was devastated and massacred by both the Germans and the Soviets. Some eight million Poles moved and settled on the territories assigned to them by the Potsdam agreement. After the war those Western territories became an essential component of their economy. 33 In these circumstances, any threat to their territorial integrity would not only reawaken the memories of the Nazi occupation but also pose the prospect of national extinction which the Poles had experienced more than once. It was in this context that even the anti-communist Poles would justify both Poland's bonds with the Soviet Union and a permanently divided Germany. 34

Even though it was precisely because of this aspect of the Rapacki plan -- to create an atom-free West Germany and strenthen its conventional forces compared with those of NATO -- that the Soviet Union gave support to the scheme, this was by no means the only motivation for the proposal. Even to those who considered the plan mereIy another Soviet propaganda move ${ }^{35}$ it seemed to be of little doubt 
that the advantages of the Rapacki plan for Poland outweighed those for the Soviet Union. With regard to their unsettled western frontier, the Poles had more reasons to be concerned about the growing tension in Central Europe than the Soviet Union. Furthermore, for the Poles, reduced tension in Central Europe would have been tantamount to lowering the artificial barrier dividing the West and the East, thus largely overcoming Poland's isolation from the outside world. In this sense, a military disengagement in that region was supposed to create a favorable condition for Poland's stepped-up economic, cultural engagement with Western Europe. This was one of its goals as confirmed by Gomulka who, in November 1958, stated that the Rapacki plan was also aimed at preventing the widening division of Europe. 36

Rapacki was a realist who believed that from the beginning any foreign policy should be based on the rigid international structure of the postwar world and the existing balance of forces. Instead of being concerned with an instant political solution to the problem, the government should be more concerned with raising the living standard of the populace, national culture, and political education of the people. 37 In putting his idea into practice, Rapacki rejected neutralism in a world divided between two superpowers. 38 For him the first purpose of Polish foreign policy should be to contribute as much as possible to the relaxation of the tension between the two camps. This led him to the decision to encourage small steps to bring about international detente. If there were less tension between the two opposing military blocs and their relations were more relaxed, 
there would be a greater role and more room for maneuver for the small-medium sized states. To pui it another way, as long as Germany remained the center of East-West tension, the foreign policy of Poland, which borders Germany, would be dictated by the Soviet Union, who was determined to take care of the German problem and who would closely supervise the moves of the states in the vicinity of Germany.

Rapacki, himself, named his reasoning "constructive coexistence", which meant, in a more concrete sense, developing good relations between Poland and the West with which Poland was linked by economic interest, historical traditions and cultural contacts. It followed that this could be realized only through sincere coexistence that could lead to a relaxation of tension and to confidence, and an end to the division of the world into two opposing camps. In a lecture at Oslo University on October 31, 1958, Rapacki explained the motives and aims behind his policy of "constructive coexistence" in relation to the German problem

On this subject I should like to speak quite frankly. In Poland there is a widespread fear of German reunification. In many other countries similar misgivings are felt much more strongly than official statements suggest. We, however, are of the opinion that reunification of Germany as a peaceful country is the condition for a complete normalisation of the situation in Europe. We naturally agree that this is a matter for the Germans alone, but at the same time we must insist upon our right to have a say in things that directly affect our security. The reunification of Germany will present serious difficulties so long as the present international tension persists and so long as Germany's great military importance in Europe continues. Thus the aim of our proposal is to reduce world tension and the military importance of the whole European zone to which our plan applies. 39

While Rapacki was in Norway, a member state of NATO, he had 
talks with Halvard Lange, the Norwegian Foreign Minister. In his conversations with Lange, he was informed that there was, in the West, a ct. ${ }^{+}$in degree of interest in his plan. 40 On November 4, 1958, Rapacki held a nress conference and issued the second variant of the Rapacki Plan. This plan took into consideration the main reason for the Western rejection of the original plan which had ignored the superior conventional forces of the Warsaw Pact in Central Europe, thus upsetting the military balance of power. This time Rapacki suggested a two-stage implementation of the proposal. In the first stage, the production of nuclear weapons would be prohibited on the territory of Poland, Czechoslovakia, and the two German states, and in addition all outside powers would agree not to supply nuclear weapons and the necessary facilities to the armies in the territory of the zone. Since none of the four countries in the zone possessed nuclear arms, this virtually would have meant the renunciation of nuclear armament by all four of them. 41 Implementation of the second stage was supposed to be preceded by negotiations concerning a corresponding reduction of conventional forces. This reduction was to have been effected at the same time as the complete denuclearization of the zone which would have required appropriate control measures. 42

This modified version of the Rapacki Plan, however, did not substantially change the stand that the Western powers had taken toward the original plan. Rapacki, himself, was reported to have been relatively pessimistic about the Western acceptance of the plan saying, "It probably would not be acceptable to the opponents of our initiative." 43 However, the West German belligerent rejection of the 
Polish proposal seemed to have been somewhat moderated, and Bonn this time commented on the Polish Foreign Minister's "considerable perserverance and flexibility," and recommended that the plan should be studied "with due care." 44

Two weeks after the revised Rapacki Plan was introduced, the British Foreign Minister, Selwyn lioyd, stated in the House of Commons that while the Polish government and its foreign minister were "absolutely sincere" in putting forward these proposals, the factor that had to govern their view of the matter was whether any plan for disengagement would be acceptable if it would change the balance of military security to the disadvantage of either side. 45 From the Western point of view, the renunciation of nuclear arms by West Germany itself meant further upsetting the military balance in Central Europe. This was because the West intended to rearm West Germany with nuclear arms if necessary, in order to balance the military situation there. Furthermore, even if the reduction of conventional forces were to be discussed it would still be unacceptable since a "corresponding" reduction of conventional forces was suggested.

However, after the second version of the Rapacki Plan was proposed, an objection was raised by the West which was beyond the scope of Polish foreign policy. The objection was that the plan would not remove the Soviet nuclear threat from Central Europe, since even shortrange Soviet missiles could reach much of Western Europe from Soviet territory. Moreover, since the whole Western strategy was dependent on nuclear weapons, acceptance of the plan would lead to the withdrawal of all American forces from Central Europe. 46 Faced with this ob- 
jection there was very little to say for Rapacki, since there was no prospect of bringing into his plan the Soviet nuclear forces within the Soviet Union.

Nonetheless, the seriousness of the Polish government in its efforts to ease the tension in Central Europe was well conveyed to the Western states. Even so, the second variant of the Rapacki Plan was still unacceptable and was buried in the weeks that followed. However, the rejection did not only came from the West but it also came from the East, which perhaps had a more negative impact on the Poles than the rejection from the West.

On October 27, 1958, while Rapacki was putting out diplomatic feelers throughout the Western states regarding the acceptability of the Warsaw Memorandum, Walter Ulbricht, First Secretary of the East German Socialist Unity Party declared that the whole of Berlin lay within the territory of the German Democratic Republic, and the whole of Berlin belonged to the area under the sovereignty of the GDR. Therefore, he continued, the authority of the Western occupying Powers no longer had any legal basis to be in Berlin. 47 On November 10, Khrushchev continued Ulbricht's statement and made clear the Soviet Union's intention to transfer control of East Berlin to the East German government. It was in a speech at a reception for a Polish government delegation led by Gomulka in Moscow that Khrushchev stated:

...At present the Western press writes a lot about the fact that the German Federal Republic is about to propose to the Soviet Union, the U.S.A., Britain and France a new fourPower conference to solve for the Germans -- and despite the Germans - the question of unifying their country. But this is the continuation of the old, unrealistic policy which contradicts common sense and has no legitimate basis. No Powers 
have the right to interfere in the internal affairs of the German Democratic Republic, or to dictate their will to it.

We quite understand the natural desire of the German people for reunification of their motherland. But the German military and their American patrons only use these national sentiments for a purpose which has nothing in common with German unity or with ensuring a stable peace in Europe. In fact, the military circles of Western Germany are following the road of deepening the division of the country, and of preparing military adventures. If the West German Government tried to solve the question of German unity, not by words but by deeds, then it would take the only road which leads to that goal -- the road of estaplishing contacts with the German Democratic Republic...48

It was this speech that started the Berlin crisis of 1961 and set the scene for the global solution of the German problem according to Soviet interests and consequently ruined the Polish efforts to decrease the tension in the heart of Europe, thus denying the prospect for an independent foreign policy of Poland. ${ }^{49}$ Gomulka was not surprised, however, having been handed a copy of Khrushchev's speech a couple of days earlier in Moscow. ${ }^{50}$ Nevertheless, the speech and its implications touched a nerve of the Poles' feeling of national security, since any negation of the then status of Berlin, and by the same token of the Potsdam Agreement of 1945, would have easily led to the negation of Poland's western frontier. Furthermore, Khrushchev, in his talks with Gomulka reminded the Polish leader that the Soviets would allow Poland some deviation with regard to internal affairs but that in the field of foreign policy Poland should not step out of its position as one of the Soviet Union's junior allies. ${ }^{51}$ The Soviet leader also discredited the recent Polish attempts to lessen the tension in Central Europe, ${ }^{52}$ and alluded that the Poles did not have any confidence in the Soviets' assurance to protect Poland's western frontier. ${ }^{53}$ In this 
way Poland's attempts to develop a foreign policy line of its own and to bring an even partial solution in Central Europe was frustrated by its powerful eastern neighbor. Even though the Polish government continued its endeavors for these purposes in the years to come, those were more restricted by the Pacts' coordination and were less significant.

On September 27, 1960, Gomulka presented again the second Rapacki Plan of two-stage denuclearization and announced to the General Assembly of the United Nations that the plan had not lost any of its pertinence. ${ }^{54}$ While paying enough tribute to Moscow, ${ }^{55}$ he reminded the audience of the need to take an initial, concrete step in order to improve the hair trigger situation in Central Europe. Gomulka stated, with his eye on Berlin:

Had the Polish government's proposal been adopted and implemented at the time, the situation in central Europe would now be completely different.... Instead of mounting armaments and threats, instead of a worsening of the German problem, we would certainly have had a climate of detente... and furthermore we would have gained valuable experience in the execution of disarmament plans and the functioning of control systems. 56

In the fall of 1961, Gomulka told a Western journalist that the Poles had never withdrawn the Rapacki Plan. 57 Furthermore, in October of that year, the whole discussion flared up again, when Senator

Hubert H. Humphrey, Chairman of the U. S. Senate Foreign Relations Committee and close associate of President John F. Kennedy, remarked in Warsaw that he considered the Rapacki plan a useful initiative. ${ }^{58}$ A proposal which later became the third variant of the Rapacki Plan was presented when the 18-Nation Disarmament committee started its deliberations in Geneva. It was submitted on March 28, 1962, in 
the form of a Memorandum on the Establishment of a Nuclear-Free Zone of Limited Armaments in Europe. ${ }^{59}$ The Memorandum was a detailed combination of the Warsaw Memorandum of February 14, 1958, and the Rapacki statement of November 4th. This proposal contained one entirely new suggestion. Instead of designating in advance which states would be involved, as was the case in previous proposals, the suggestion was to make accession to the nuclear-free zone entirely voluntary. The previous concession made to West Germany that it would not have to negotiate with East Germany was dropped. 60

This third variant did not arouse much enthusiasm in the West and was not studied seriously. Indeed, in the same period the Soviet Union forwarded to the Western Powers its grand plan of "total disarmament." It proposed the disbandment of armed forces, the dismantling of bases, and the destruction of war material in three stages which would be extended over four years or any other agreed period. ${ }^{61}$ This all-ornothing approach emanating from Moscow clearly signaled to the West the difference between the Soviet initiative and Poland's more modest but realistic approach for an initial concrete step. This difference definitely contributed to the West's reluctance to deal with the Polish proposal with due seriousness, for whenever they found a differenee in approach between the Soviet Union and Poland, the Western states had (this time even more serious) doubts about the latter's ability to implement its plans.

In his speech in Plock, Poland, on December 28, 1963, Gomulka again let it be known that the Rapacki Plan was still alive. As had happened since 1958, the Polish proposal was again accompanied by a 
Soviet proposal for a general and complete disarmament. This time, Gomulka proposed a nuclear freeze in both Germanys, Poland and Czechoslovakia, which would be monitored by NATO and the Warsaw Pact teams. In effect, this proposal made a separable plan of the first stage of the second Rapacki Plan, and thus was limited to a freeze on nuclear weapons. The proposal also urged a non-aggression pact between NATO and the Warsaw Pact. ${ }^{62}$ This fourth variant of the Rapacki Plan of December 1963 -- this time properly known as the "Gomulka Plan" -- was to serve Polish interests insofar as it prohibited West Germany from acquiring thermo-nuclear weapons. The Gomulka Plan, like the Rapacki plans, again ignored the degree to which the West was disturbed by the concentration of Soviet Medium-Range Ballistic Missiles on the Soviet western frontiers. ${ }^{63}$ Although some Western statesmen demonstrated interest in the Polish proposal, the plan was not taken into serious consideration.

As discussed above, since West Germany was admitted to NATO by the Paris Agreement, Poland strove to prevent the emergence of a powerful West German state. It particularly attempted to prohibit Bonn's acquisition of nuclear arms. The Polish fear of a strong German state was directly related to the unsettled Polish Western frontier, as well as the Poles' historical experience. Therefore, the repeated Rapacki plans aimed at alleviating the fear of potential German aggression. In more concrete terms, they assumed, during the forseeable future at least, divided Germanys without nuclear forces, thus defining a very subordinate nature to Germany's role in the European security system. However, the Rapacki plans by no means excluded all the possibilities of German 
unification. As Dr. Manfred Lachs, Rapacki's legal advisor, notes:

One can by no means conclude from this that the (Rapacki) plan is directed against Germany's reunification or could in any way hinder it. The very opposite follows from the logic of the proposal. Every sober-minded politician clearly understands that the existence of two German states is a fact and that recognition of this fact must be the point of departure for any plan to unify Germany. Every sober-minded politician must realize that any increased arming of West Germany, any step in building up the Bundeswehr, hampers and delays the settlement of the German question. The greater the military might of West Germany, the more difficult will it be to reunite the country. ${ }^{6}$

Poland could easily have accepted a harmless, unified Germany which could in no way pose a danger to Poland's security interests. This Polish desire for a harmless Germany was shared by the Soviets, but it would be naive to identify the Polish proposals with those of the Soviets'. ${ }^{65}$ The Rapacki plans were not only derived from a genuine Polish interest but they also aimed their political edge at the Russian overlordship. Indeed, the Western acceptance of a Rapacki plan would have strengthened the Soviet Union's offensive nuclear potential enormously. Therefore, it would have resulted in a redistribution of nuclear power on the European continent in favor of the Soviet Union, and in relative preponderence of the Soviet conventional forces. However, the measures for disengagement in Central Europe were not without risks for the Soviets. The withdrawal of Soviet troops (even a partial one) from Central Europe would have brought about a partial liberalization in that region. 66 For the Poles, the withdrawal would have given them greater security against the possibility of Soviet invasion. This was particularly true with regard to East Germany, because the disengagement would have undermined the unpopular 
Ulbricht regime. 67 Furthermore, the acceptance of a Rapacki plan would have greatly lessened the possibility of German revanchism, thus giving the Poles a sense of security concerning the Oder-Neisse frontier.

These developments would have largely overcome Poland's isolation from the outside world. The Poles could have cultivated closer relations with the West owing to the lowered barrier dividing Europe on the one hand, and to the lessened Soviet influence, on the other. Given these positive factors, the Poles would have gained more room for their independent foreign policy. 


\section{NOTES FOR CHAPTER I}

${ }^{1}$ M. Gribanov, Security for Europe: Prospects for an All-European Conference, (Moscow: Novosti Press Publishing House, 1972), p. $22-23$. Signatories to the treaty were to pledge themselves not only to refrain from attacking one another, as well as to refrain from the use of force or the threat of force, but also to refrain from participating in coalitions directed against other signatories of the treaty. Thus, for the NATO member states, it would have been incompatible with their interest to enter into this treaty.

2 The agreement also included the following:

(1) The United States, Britain and France terminated the occupation regime in West Germany and recognized it as a sovereign state.

(2) West Germany and Italy acceded to the Brussels Treaty and the Western Union became the Western European Union (WEU). There was to be extremely close cooperation between the WEU and NATO.

(3) The United States and Britain undertook to maintain, for as long as necessary, their force on the European continent. NATO Information Service, NATO: Facts and Figures, (Brussels: 1976) p. 36 .

3 Polish Institute on International Affairs, Conference on Security and Cooperation in Europe: A Polish View, (Warsaw: Polish Scientific Publishers, 1976), p. 17.

4 Robin Alison Remington, The Warsaw Pact: Case Studies in 
Communist Conflict Resolution, (Cambridge, Mass.: The MIT Press, 1971) p. 17 .

\section{Conference on Security and Cooperation in Europe: A Polish}

View, op. cit., p. 18 .

6 The Socialist countries attempted to symbolize the aggression of the West by claiming that West Germany joined NATO exactly 10 years after the Second World War. Ibid., p. 19.

However, the accession of the FRG to NATO became effective on May 5 , 1955, whereas W. W. II in Europe ended with the unconditional surrender of the German armed forces on May 7, 1955.

7 Two months after the ratification of the Paris Agreement, the Soviet Union made one last major attempt to reverse the effects of the agreements at the Geneva Summit Conference in July, 1955, where Soviet Premier N. H. Bulganin reintroduced a draft of a European security treaty by which the North Atlantic Treaty, the Paris Agreements, and the Warsaw Treaty would have simultaneously ceased to operate. See A. Ross Johnson, The Warsaw Pact's Campaign for "European Security" (Santa Monica, CA: Rand Corporation R-565-PR, November, 1970), p. 5.

8 Remington, op. cit., p. 204.

9 For example, on July 19, 1963, Khrushchev proposed a nonaggression pact between the two military organization.

10 Zbigniew Brzezinski, Alternative to Partition, (New York: McGraw-Hill Book Company, 1955), p. 86.

II Richard Hiscocks, Poland: Bridge for the Abyss?, (London: Oxford University Press, 1963), p. $257-258$. However, towards the end of the year, the Polish-Chinese relations 
cooled down, and Mao's visit was cancelled. The Polish view of the Chinese as a strong liberalizing factor in the Soviet bloc was finally turning out to be unfounded. As Batinski notes: "Despite Chou's visit to Poland, despite his insistence on Soviet leadership, despite the clear line drawn between internal autonomy and external obeisance....the Poles continued to picture the Chinese as their allies in the struggle against centralist tendencies, particularly against a reassertion of effective Soviet leadership." Zbigniew. K. Brzezinski., The Soviet Bloc, (Cambridge, Mass.: Harvard University Press, 1977), p. 297.

12 Adam Bromke, Poland's Politics: Idealism vs. Realism, (Cambridge, Mass.: Harvard University Press, 1967), p. 129. Hiscocks, op. cit., p. 260.

14

Hansjakob Stehle, The Independent Satellite, (New York: Praeger Publishers, 1965), p. 34. Gomulka persuaded Tito on the assumption that the Yugoslav recognition of East Germany would cause a chain reaction which would relieve Poland of its German problem and remove the pressure on its western border. The assumption was also that the Hallstein doctrine had proven ineffective and West Germany would not apply it to Yugoslavia, which turned out not to be the case.

15 Hiscocks, op. cit., p. 258.

In spite of Gomulka's assertion that there was no strings attached to the aid, Moscow criticized it by claiming, "Accepting economic aid from America will amount to a betrayal of socialism." See Bromke, op. cit., p. 135. 
Moreover, during the same period, only Poland, of all the Communist countries, established friendly political and economic relations with Israel. On October 16, 1957, a special trade agreement was concluded between the two countries. At that time, the Soviet Union and the other Pact's members accused the Israelis of their imperialist crimes. See L. B. (initials only), "Revisionist Poland", World Today, June 1958 (p. 247-259), p. 252 .

16 P. Jaszonski, "Poland and the Nonnuclear Zone", International Affairs (Moscow), April, 1964, (p. 28 - 35), p. 28.

17 stehle, op. cit., p. 222.

18 Ibid.

19 Vaclav L. Benes and Norman J. G. Pounds, Poland (New York: Praeger Publishers, 1970), p. 371.

20 Ibid.

21 Ibid.

22 stehle, op. cit., p. 223.

According to Benes and Pounds, Czechoslovakia supported the plan at the same General Assembly session.

23 The memorandum was transmitted to the governments of the U.S.S.R., the United States, Great Britain, France, Czechoslovakia, East Germany, Belgium, Denmark and Canada. To the West German government, it was transmitted through the offices of Sweden. Andrzej Albrecht, The Rapacki Plan-- New Aspects, (Warsaw: Zachodnia Agencja Prasowa, 1963), p. 29.

24 Jaszunski, op. cit., p. 29.

25 Rapacki and his legal adviser, Professor Manfred Lachs, left 
for Moscow in secrecy and uninvited. The negotiation between the Polish Foreign Minister and the reluctant Soviet leaders took place from January 28 to February 1, 1958. For more details on the negotiations, see Stehle, op. cit., p. $225-226$.

26 See note 14. It was also applied to Cuba in 1962.

27 For a full text of the document, see Albrecht, op. cit., p. $60-73$. The obligations of the great powers were also to be embodied in the form of a mutual document or unilateral declarations. 28 Ibid.

29 For example, see Hugh Gaitskell, "Disengagement: Why? How?", Foreign Affairs, July, 1958, (p. 538 - 348). "...I regard the Rapacki Plan as an advance....nevertheless a plan which simply involved a nuclear-free zone in that area would not be acceptable to the West because it would probably upset the balance of security to their disadvantage." p. 546.

30 Stehle, op. cit., p. 228.

31 The American note, even though courteous, pointed out the plan's "lack of method for balanced and equitable limitations of military capabilities" and "accepting the continuation of the division of Germany." See Bromke, op. it., p. 131.

32 Benes and Pounds, op. cit., p. 373.

33 In Poland these Western territories were referred to as "Recovered Territories". Poland claimed its right to the estern territories by citing the theory of a "historical nationality" that had existed for nine centuries. Poland also based its claim on the fundamentally Slav character of the region as well as on the inter- 
pretation of the Potsdam Conference as a "preliminary peace". For the theory of a "historical nationality" and the Slav character of the region, see flans Roos, A History of Modern Poland, (London: Eyre and Spottiswoode, 1966), p. 279 - 280. For the Polish interpretation of the Potsdam Conference as a preliminary peace, see Alfons Klafkowski, The Polish-German Frontier after W.W.II. Iranslated by Edward Rothert, (Poznan: Wydawnictwo Poznanskie, 1972), p. 106 - 122. Also concerning the importance of the Recovered Territories as "Poland's Katanga", see Richard Hiscocks, "Progress East of the Oder-Neisse", World Today, November, $1960,(p .491-500)$.

34 poland's fear was even more intensified by the so-called "Strauss Law". It was a resolution adopted by the West German Bundestag in March, 1948, which demanded atomic weapons for the West German Bundeswehr. The resolution, adopted by the Bonn legislative authorities was the first document of a state character to contain an official demand for nuclear arms. Gomulka called it the "Strauss Law", because the then West German Defense Minister, F. J. Strauss, was the main advocate of the resolution. See Wladyslaw Gomulka, On the German Problem, (Warsaw: Ksiazka i Wiedza Publishers, 1969), p. 127 128.

As to the effect of the unsettled Oder-Neisse frontier on the Poles attitude toward the Soviet Union, there exists a view in the West that the Soviet Union intentionally let Poland push its territory to the Oder in order to make its dependent on Soviet support for the defense of this border, and thus virtually to chain it to the soviet Union. However, what this argument ignores is that in 1945, neither 
the Russians nor the Poles could anticipate that, after agreeing to the removal of the German population from this territory, the West would refuse to recognize its acquisition by Poland as final. And it was only in the light of this inconsistent position that the Soviet Union emerged as the sole champion of Poland's right to the frontier along the Oder-Neisse line. See.Adam Bromke, "Polish Nationalism and Communism", Foreign Affairs, July, 1962, (p. 635 - 643), p. 640n. 35 For example a view expressed in World Today, "Unless the Rapacki Plan is nothing but a propaganda stunt, it would not have received that measure of enthusiastic support from the Soviet Union." H.A. (initials only), "Changing Relationships in Eastern Europe", World Today, February, 1958, (p. $54-60$ ), p. 60 . 36 Bromke, Poland's Politics, op. cit., p. 130.

Benes and Pounds note that Poland by proposing the Rapacki Plan, aimed at establishing a bridge between East and West. Benes and Pounds, op. cit., p. 370 .

37 M. K. Dziewanowski, Poland in the 20th Century, (New York: Columbia University Press, 1977), p. 193 - 194.

38 Ibid. Adam Rapacki was born in 1909 to a family with a long intellectual and socialist tradition. His father was a university professor and a prominent leader of the cooperative movement.. Before W. W. II, Rapacki studied in Poland and Western Europe and was active in the socialist youth organization in Warsaw. He spent the wartime as a prisoner of war in Germany. Upon his return home in 1945, he joined the pro-Communist Polish Socialist Party and soon: emerged as one of the closest associates of J.ozef Cyrankiewicz. After the party's 
merger with the Communist Party in 1948, he entered its Politburo. Demoted to a candidate nember in 1954, he was restored to full member in 1956, and in the same year took charge of the Foreign Ministry. Dziewanowski considers Rapacki a successor of Roman Dmowski in terms of their political realism. Adam Bromke also highly evaluates Dmowski for his realistic thinking and as the founder of modern Polish nationalism. Dmowski ruled out neutralism for Poland considering its geographic position, considered Germany the archenemy of Poland, and regarded Russia as Poland's potential partner in Poland's struggle for independence. Bromke, op. cit., p. 14 - 18 passim. Bromke also finds Dmowski's influence in Polish foreign policy at the beginning of the 1970's, see Bromke, Adam, "Polish Foreign Policy in the 1970's", in Adam Bromke and John W. Strong (eds.) Gierek's Poland, (New York: Praeger Publishers, 1073) p. $203-204$. 39 Stehle, op. cit., p. 223. 40 Ibid., p. 228-229 41 Jaszunski, op. cit., p. $29-30$. 42 For a full text of the statement, see Albrecht, op. cit., p. $87-90$.

43 Bromke, op. cit., p. 131.

44 Stehle, op. cit., p. 229. After Rapacki proposed his second plan, even Franz Josef Strauss wrote in Foreign Affiars, "I do not wish to say anything against planners of this plan. Their efforts are doubtless well meant." Strauss, "Soviet Aims and German Unity", Foreign Affairs, April, 1959, (p. 366 - 377), p. 373. However, he still thought the plan would lead to one-sided disengagement of the 
West. In contrast, the German Social Democratic Party had been supporting both the first and second version of the Rapacki Plan. See Keesing's Research Report, Germany and Eastern Europe since 1945, (New York: Charles Scribner's SOns, 1973), p. 146. Also P. J. D. (initials only), "The Pursuit of Disengagement", World Today, April, 1959 , (p. $156-168)$, p. $161-162$.

45 Keesing's Research Report, op. cit., p. 147.

46 Henry A. Kissinger, "Missiles and the Western Alliance", Foreign Affairs, April, 1959, (p. 385 - 401), p. 395. Also, Albrecht, op. cit., p. $32-33$.

47 Ibid., p. 153.

48

Ibid., p. $150-151$.

49 Polish officials were reported to have said that the Rapacki Plan had been given a "solemn State funeral". P. J. D. W., "The Pursuit of Disengagement", op. cit., p. 158.

A view was expressed that this was a Soviet tactic to combine the stick (Khrushchev's hard stand on Berlin) and the carrot (the Rapacki $\mathrm{Plan}$ ) in order to elicit a favorable response from the West. For this view, see Franklyn Griffiths, Lincoln P. Bloomfield and C. Clemens Jr., Khrushchev and the Arms Race, (Cambridge, Mass.: The MIT Press, 1966), p. $148-150$.

50 Stehle, op. cit., p. 39.

51 Ibid.

52 Khrushchev, confident that Gomulka would follow whatever initiatives Khrushchev would take, "seems prepared to humour Poland's claims to assert her identity on the international stage." Hiscocks, 
op. cit., p. 261.

53 Stehle, op. cit., p. $39-40$.

54 Ioid., p. 324.

55 At the same session, Khrushchev ostensibly submitted the Basic Provisions for a Treaty on General and Complete Disarmament. Jaszunski, op. cit., p. 30 .

56 stehle, op. cit., p. $324-235$.

57 Jaszunski, op. cit., p. 31.

58 Senator Humphrey stated, "I feel that the proposal of the Polish Foreign Minister is a constructive proposal. I believe that it was offered in an effort to reduce international tension and that it deserves a very serious consideration by all the powers. President Kennedy, with a new policy and a new disarmament program, and the Disarmament Agency will be giving the Rapacki Plan and other plans to reduce armaments and to prevent the spread of the arms race very, very thoughtful and serious study and consideration. We look upon the Rapacki Plan and others as a part of our general program for seeking disarmament that will reduce this terrible arms burden." Albrecht, op. cit., p. 102. However, this statement was quickly disqualified by Washington.

59 Albrecht, op. cit., p. 61.

60 For a full text of the memorandum, Ibid., p. $61-65$.

61 Jaszunski, op. cit., p. 30.

62 Ibid., p. $33-34$.

63 Brzezinski, Alternative to Partition, op. cit., p. 87.

In June 1964, in response to a West German inquiry, the Poles made it 
clear that the Gomulka proposal for a nuclear freeze did not include the USSR.

64 Lachs, Mandred, "Atom-free Zone in Central Europe", International Affairs, (Moscow), August, $1959,($ p. $19-23)$, p. 20.

65 The view which identifies the Rapacki plans with the Soviet aims is expressed, for example, by Laszlo Gorgey, Bonn's Eastern Policy: 1964 - 1971, (New York: Archon Books, 1972) p. 43. Gorgey maintains, "Closer scrutiny of the Polish plans to bring about a European 'disengagement', or to create a 'demilitarized zone' in Central and Eastern Europe, or even the proposal to establish a 'nuclear-free zone' in the same area strongly suggests that Polish foreign policy has in fact been designed primarily to help perpetuate Soviet predominance on the European continent."

66 P. J. D. W. (initials only), "The Pursuit of Disengagement", op. cit., p. 150 - 161. See also Griffiths, Bloomfield, and Clemens, o․ cit., p. $150-151$.

67 For the risks of the Rapacki Plan, especially for the Ulbricht regime, see Griffiths, Bloomfield, and Clemens, op. cit., p. 223. 
CHAPTER II

POLISH FOREIGN POIICY AND THE PROPOSALS FOR

THE CONFERENCE ON SECURITY AND COOPERATION IN EUROPE

The repeated Polish proposals were transformed into the plan for a general conference on European Security and cooperation in 1964 . This very proposal was the genesis of the Conference on Security and Cooperation in Europe (CSCE) which lasted from July 1973 to August 1975. I It took almost a decade to convene such a conference. Throughout the campaign for the CSCE, Poland strenuously pursued its two basic goals: (1) to gain formal recognition of the oder-Neisse boundary and (2) to cultivate and consolidate its relations with the Western countries that would strengthen its position in both Western Europe and the Soviet bloc. However, attainment of the second objective largely depended upon achievement of the first objective. The fear that West Germany might some day reoccupy Poland's western territories made the Poles defensive and their approach toward the West in general, rather reactive. This fear was intensified as West Germany emerged as a great power in Europe. Moreover, in order to secure its western frontier, Poland had to seek whatever support it could get for that purpose within the Soviet bloc, thus giving the Soviets greater say in their relations with Poland. This made Polish foreign policy closer to that of the Soviet Union and East Germany, the latter of which shared with Poland the fear of "West German Revanchism". This objectively 
negative circumstance notwithstanding, Poland never neglected its efforts to narrow the division of Europe and create a favorable condition in which Poland could regain its ties with the West.

On December 14, 1964, after Khrushchev's ouster, at the 19th Session of the UN General Assembly, the Polish Foreign Minister, Rapacki, made a proposal to convene an all-European Conference to examine the problems of continental security in their entirety. He stated:

... We also believe that the time has come to discuss the whole problem of European security. We should consider the possibility of calling a conference of all the European countries, naturally with the participation of the Soviet Union and the United States, to discuss the matter. Such a conference could be prepared -- if this was considered purposeful -- by representatives appointed by the organization of the Warsaw Treaty and the organization of the North Atlantic Treaty and, if it was found desirable, by representatives of those European countries which do not belong to these two groupings.?

Rapacki's initiative was promptly endorsed in January 1965

(in Warsaw) by the Pact's Political Consultative Committee (PCC) which met in order to consider appropriate responses to the possibility of West Germany participating in NATO's multilateral nuclear force project $(M L F) .{ }^{3}$ However, its endorsement was qualified because the PCC did not agree to U. S. participation or to Rapacki's formula for the conference preparations. ${ }^{4}$ The PCC statement also proposed a NATOWarsaw Pact non-aggression treaty and reaffirmed the Pact's opposition to NATO's multilateral nuclear force project which they believed amounted to an unacceptable transfer of control over nuclear weapons to West Germany. If the MLF were established, it said, the Pact would have to take appropriate military countermeasures. ${ }^{5}$ In the statement 
the PCC paid tribute to the Rapacki Plan and called for a freeze on nuclear weapons in Europe. ${ }^{6}$ The Pact leaders also demanded the acceptance of existing borders and the liquidation of the remnants of World War II. In this statement, however, they did not demand recognition of East Germany but threatened that if Bonn gained control over nuclear weapons, reunification would become impossible. ${ }^{7}$ Thus, two of the most important objectives of the 1964 Rapacki proposal for the CSCE were to prevent NATO from establishing the MLF and the West German acquisition of a nuclear force, and to achieve multilateral guarantees of the Oder-Neisse border.

The CSCE proposal reappeared in January 1966, in an East German government proposal on European Security. It emphasized the importance of partial disarmament measures and recognition of the GDR. Two months later Leonid I. Brezhnev in his report to the Twenty-third Congress of the CPSU outlined the purposes for which he wished such a conference to be convened:

To discuss the existing proposals of the socialist and other states of Europe concerning a military detente and the reduction of armaments in Europe and the development of peaceful, mutually advantageous ties among all European states.... To continue to seek ways for solving one of the cardinal tasks of European security -- the peaceful settlement of the German question with a view to eliminating completely the vestiges of World War II in Europe on the basis of recognition of the now existing European frontiers, including those of the two German states. 8

However, between December of 1964 and the Brezhnev report of March 1966, the Soviet Union was not as enthusiastic over the scheme as some of its allies. ${ }^{9}$ Romania and Hungary as well as Poland were particularly active in their campaign for the conference. Within 
NATO, Belgium, the Netherlands, and Denmark showed the most interest. These countries opened a variety of bilateral discussions on the proposal. These discussions to a large measure focused on the complexity of the issue and the exploration of additional means for encouraging wider interest among their respective allies. Poland took every opportunity to promote the scheme forwarded by Hungary to create a fourPower preparatory committee (Hungary, Poland, Belgium and the Netherlands) in order to consider formally an agenda for a European Conference. ${ }^{10}$ Poland, for its part, also proposed an alternative six-Power preparatory committee. $^{11}$ While Western skepticism prevailed, Warsaw could report by 1966 that its energetic campaign for the purpose of convocating a European Conference had born some fruit. In an interview with Trybuna Ludu in December 1966, Foreign Minister Rapacki pointed to Denmark and France as two countries where "a meeting of minds" existed on European security issues. ${ }^{12}$ In this context, he cited a consensus on the prevention of nuclear proliferation in Europe, recognition of the two sovereign German states, and recognition of existing European borders. ${ }^{13}$ These enthusiastic campaigns reflected the assessment, by Poland and the other Warsaw Pact states, that progress of detente between the two military blocs could greatly increase their freedom of maneuver in foreign policy.

Parliamentarians from ten European states were organized into a semi-official body to discuss the issue of an all-European Conference. ${ }^{14}$ The World Peace Council (WPC) took up the banner of European security in reaction to autonomous initiatives in some West European states. ${ }^{15}$ In July, 1965, for instance, a WPC-sponsored "peace congress" in 
Helsinki endorsed the proposal for an all-European Conference, and in June 1966, a WPC session in Geneva adopted a "Memorandum on European Security" endorsing the CSCE project. 16

The Rapacki proposal for an all-European Conference was taken up in a conference of the Warsaw Pact's Political Consultative Committee in Bucharest in July, 1966. This was the first in a series of major meetings of communist leaders substantially devoted to promoting the CSCE idea. This, in turn, indicated enthusiasm on the part of the Soviet Union in holding such a conference. The principal objective of convening the CSCE was set forth as an all-European commitment to cooperation for the purpose of maintaining and strengthening security in Europe. 17 This security was to ensure the sovereignty, equality, independence, noninterference in domestic affairs, and territorial integrity of all European states. It was to be based on renunciation of the threat of force or use of force. International disputes were to be solved only through peaceful means. In specific terms, the Bucharest declaration emphasized recognition of the existing boundaries, including the Oder-Neisse, exclusion of West Germany from access to nuclear weapons, replacement of military alliances with a new security system once the NATO countries had agreed to liquidate their organization, and promotion of economic, scientific and technical cooperation.

The declaration then went on to identify the United States and West Germany as the chief villians threatening peace in Europe and deepening its divisions. It further pleaded for peaceful coexistence between states with different social systems. Besides the call for the simultaneous abolition of NATO and the Warsaw Pact which would be 
replaced by a European security system, the statement advocated partial measures for detente. 18

The declaration spoke of a "German peace settlement" and a future German "reunion" (implying much less than reunification), and said it could be achieved only through a "general rapprochement between the two sovereign German states. ${ }^{19}$ But the language used made it clear that such a unified Germany could only be a Communist Germany and was, in any case, a distant prospect at best.

The declaration revealed Soviet aims in convening the CSCE fairly clearly: (1) prevention of the United States from playing a role in Europe, (2) stabilization of the status quo in Europe, thus Iegalization of its control over Eastern Europe, (3) an inducement to neutrals to support the idea of an all-European Conference and (4) extension of Soviet influence to Western Europe. Even though the Bucharest declaration called for the simultaneous abolition of NATO and the Warsaw Pact, the consequences would be rather one-sided. For, while the United States would be pushed out of Europe, the Soviet Union would maintain its bilateral alliances with its East European allies. In fact, in this period, the Soviet Union was adopting a differentiated approach towards the West: a hardening of its attitude toward the U.S., and, at the same time, a continued, or even stepped-up, detente policy towards Western Europe with the exception of West Germany. 20 Indeed, in pursuing the goal of holding an all-European Conference, Poland's interests and those of the Soviet Union were identical up to a certain point. By the West's recognition of the postwar status quo, Poland was to obtain a nultilateral recognition of the Oder-Neisse 
boundary. For the Soviets, recognition of the postwar status quo on the part of the West would be tantamount to recognition of the Soviet empire in Eastern Europe, thus legalizing its sway over that region. 21 Also, prevention of West Germany from acquiring nuclear arms was favored by both countries. This would relieve the Poles of their genuine apprehension and for the Soviet's, it would be beneficial in their strategic consideration. Moreover, both Poland and the Soviet Union favored closer economic, scientific and technical cooperation with the West.

Nonetheless, beneath these common interests lay sharp differences between the Soviet aims and those of Poland. Whereas the Soviets hoped to achieve crystallization of the division of Europe through recognition of the existing borders, the Poles, on the other hand, viewed recognition of the borders as merely a starting-point to decrystallize that division. For the Poles, recognition of existing borders would mean: 1) lessening their dependence on the Soviets and on the bloc as a whole because they no longer would need to seek support from them to secure the Oder-Neisse line, which in turn would give Poland more overall freedom in its foreign policy formulation, and 2) lessening of tension in Central Europe, since the West's recognition of the existence of the two Germanys would lead to a decrease of the stakes both military blocs had in that region. Therefore, Poland, through recognition of its western frontier, hoped to decrease the sway of the Soviet Union over it and to establish closer ties with Western Europe.

The Soviets, for their part, were not unaware of the danger which recognition of the existing borders in Europe could pose to their rule 
in Eastern Europe. The fixation of borderlines could easily

facilitate the loosening of their grip over that area, ${ }^{22}$ for it would amount to throw away one of the important factors which maintained negative cohesion of the Soviet bloc. In other words, the bloc countries would lose another of their few common denominators which bound together those reluctant allies of the Soviet Union. Therefore, Moscow, by holding the CSCE, wanted the Western recognition of the existing borders and subsequent pan-European cooperation, but at the same time tried hard so that they would not contribute to eroding its influence in Eastern Europe.

Another call for a European Conference was issued by the Conference of the Communist and Workers' Parties of Europe (with the conspicuous absence of Romania and Yugoslavia) which took place in Karlovy Vary, Czechoslovakia, in April, 1967. The conference adopted a document entitled, "For Peace and Security in Europe", that gave full support to the proposal of calling a conference on security and cooperation in Europe. The contents of the document were basically the same as that of the Bucharest declaration. The United States and West Germany were again the main targets of the document. The uncertainties about the future of NATO, caused largely by France's repudiation of its military obligations and the difference of views between the United States and its European allies on Vietnam, were discussed as providing an opportunity to exploit the organization's crisis. 23 Referring to the opportunities which had opened up in Europe in connection with the approach of the time for a decision by the NATO powers on whether to extend the Western alliance, Brezhnev declared: 
In our opinion it is very right that Communists and all progressive forces are endeavoring to make use of this circumstance in order to develop on an ever wider scale the struggle against preserving this aggressive bloc.... Recent years have shown especially clearly that in conditions of relaxed international tension the needle of the political barometer moves to the left. Certain shifts in the relationships of Communists and Social Democrats in some countries, a noticeable decline in anti-Communist hysteria, and an increase in the influence of West European Communist Parties are connected in the most direct way with a marked easing of tension on the European continent.24

The conference also emphasized the integrity and political independence of the GDR, and the Warsaw Pact states were requested to establish closer cooperation with it. 25 Full support was given to the nuclear non-proliferation treaty, but the Rapacki Plan was drastically transformed into the proposal which listed five European regions where atom-free-zones could be established. 26 Even in April, 1967 , after NATO support for the multilateral nuclear force project (MLF) had waned, the Polish leaders did not spare their attack on West German Revanchism. At the Karlovy Vary meeting, Gomulka stated:

What is the main obstacle in the path (of a system of collective security in Europe)?

The main obstacle has been and remains the policy of the German Federal Republic.

This state was born out of the notorious marriage of US anti-Communism and the revanchist endeavors of the posthumous children of German imperialism. The marriage contract of this wedding brought about the remilitarization of West Germany, the negation of the Potsdam Agreements, on which the anti-Nazi coalition was to base the post-war order in Europe. This marriage contract has become the basis of the cormon policy of the United States and the German Federal Republic. The German Federal Republic was drawn into the Atlantic Pact and transformed into a bridgehead of the cold war and a main bastion of the antiCommunist crusade. As a reward, the Bonn governments were given a free hand to usurp the right to sole representation of Germany, to question the frontiers agreed upon in Potsdam: they also received considerable aid in the re-establishment and rearmament of the Bundeswehr.27 
The next round of appeals for the CSCE was adopted by the Political Consultative Committee of the Warsaw Pact in Budapest on March 17, 1969. Between the Karlovy Vary conference and the Budapest conference two years later, some bilateral consultations between individual Pact members and the NATO counterparts as well as the neutral countries on the question of European Security took place, but no more joint bloc appeals were issued. The long delay of any new joint initiative may be explained partly by the fact that the then developing Czechoslovak crisis preoccupied the Warsaw Pact leaderships from January to August of 1968, and also by the fact that the ensuing military occupation of Czechoslovakia by the Warsaw Pact forces called into question some of the proposals contained in the 1966 Bucharest declaration. 28 Indeed, the press campaign that attempted to justify the occupation repeatedly emphasized the necessity of strengthening the Warsaw Pact alliance in order to provide a shield to the socialist unity of its members. Thus, the Czechoslovak crisis provided an incentive to the Warsaw Pact campaign for the CSCE rather than prevented the endeavor. Nevertheless, the PCC meeting renewed the Bucharest appeal in a slightly more conciliatory and persuasive tone that attracted more than usual interest in the West.

At the Budapest Political Consultative Committee meeting, a statement was published entitled, "Message from the Warsaw Pact States to All European Countries." It advanced three relatively concrete proposals for furthering European detente: (1) strengthening political and economic cooperation among European states, (2) acceptance of the status quo and pursuit of a solution to the German problem, and (3) 
convening the CSCE. The statement was significantly milder in tone in contrast with the earlier declarations in the sense that it stopped short of blaming the United States, West Germany or NATO for the continuing division of and tension in Europe. 29

In the period between December 1964, when Rapacki first proposed an all-European Conference on security and cooperation in Europe, and the Budapest Appeal of 1969, Polish foreign policy was characterized by the following: (I) its vigorous efforts both in the west and East to promote the proposal for an all-European Conference, (2) its efforts to secure Poland's western border, i.e., the Oder-Neisse frontier, and its multilateral recognition, (3) various attempts to prevent West Germany from becoming a military giant in Central Europe, let alone it acquiring nuclear weapons and (4) its close alliance with the GDR and the Soviet Union.

In 1964, before Rapacki's proposal for the CSCE, Poland was suffering from the nightmare of Rapallo. In January of that year, Khrushchev told Gomulka of his intention to seek better relations with West Germany when he met the Polish leader at Lansk in north-east Poland. 30 Khrushchev said that he would shortly go to Bonn for that purpose and that the anti-West German campaign, which was the pillar of the Warsaw Pact's foreign policy, should be lessened. 31 That summer Khrushchev's son-in-law, Aleksey Adzhubey, editor of Izvestiya and the Soviet leader's unofficial personal ambassador, visited Bonn and produced broad hints of an ease-up in the Soviet anti-German hostility, perhaps on the conditions originally suggested by stalin in 1952 -German neutralization in exchange for reunification. 32 Moreover, 
Adzhubey hinted that Walter Ulbricht had cancer and would be replaced shortly by a new leader who was expected to be less dogmatic and easier to deal with. 33 Alarmed by the Soviet move, Gomulka, in September, 1964, took the unusual step of addressing the Writers' Congress in Iublin. On the occasion he strongly expressed his view that if peace were to be maintained, a Soviet-German rapprochement was out of the question. 34 Khrushchev fell soon afterwards. However, it is probable that the fact that he proposed a new policy toward the German problem contributed to his departure in one way or another, since that new policy was quickly reversed as soon as Khrushchev and Adzhubey left the political scene.

The whole affair touched on an agonizingly sensitive spot for the Polish leaders. They saw the possibility that some sort of sell-out of East Germany might be arranged between the Soviet Union and West Germany. The Poles were horrified by the prospect that they might lose East Germany, a buffer state of Poland against the danger of West German revanchism. From the Polish point of view East Germany was a vital wedge between Poland and the larger German state which had still not accepted the territorial losses imposed on it in 1945. 35 Thus, the fact that Poland had had a hairsbreadth escape from becoming yet again a matter of Russian-German bargaining made the Polish leaders skeptical and even more hostile toward West Germany. Indeed, they hoped that Poland's scathing hostility toward the FRG would make it difficult for the Soviet Union to reach any kind of accord with it. Another important consequence of the Polish fear was its close alliance with East Germany. 36 Therefore, Polish foreign policy between 1964 
and mid-1969 was to a large extent characterized by its strenuous attempts to increase the anti-West German elements of the CSCE project. In their approaches toward the West, and especially toward West Germany, Poland and East Germany shared common security problems. Both countries were guided by their perception of the potential threat to their territorial security posed by West Germany. Throughout all the years since the founding of the West German state until the victory of the Social Democratic Party in October, 1969, Bonn had been adamant in its claim to represent all the German people and in its aim of reunification (as to Bonn's new Ostpolitik, see Chapter 3). Because of this Bonn's stand and its Hallestein doctrine, most non-Communist governments had refused to extend diplomatic recognition to the GDR. From the view point of the East German leaders, the situation presented a triple threat; to its own legitimacy, to the future of communism in East Germany, to the very survival of the GDR as an independent state. Not to mention, Poland had similar problems in the sense that Bonn had been refusing to recognize the finality of the Oder-Neisse boundary, thus perpetuating Polish fears that West Germany might some day seek to regain the territories it lost to Poland at the end of World War II. These fears were compounded by the apprehension that Bonn might eventually get access to nuclear arms. Therefore, Poland sought to bolster its own claims by giving equal priority to making common cause with the GDR. More specifically, Gomulka subordinated Poland's interest in West German recognition of the Oder-Neisse to Ulbricht's demand for West German recognition of East Germany. 37 
In the course of their campaign for the CSCE, Poland and East Germany showed staunch solidarity. ${ }^{38}$ They maintained the position that any significant development in European detente would require the West's (particularly Bonn's) irrevocable acceptance of the postwar status quo, i.e., the diplomatic recognition of East Germany as a sovereign state and the inviolability of the western frontier of Poland. In order to bolster their claims they also needed the unified Pact's approach toward West Germany. Understandably, when, in January of 1967, Romania and West Germany established diplomatic relations, Poland and the GDR showed much greater dismay than did the Soviet Union. From their point of view, the FRG was being granted recognition by the Warsaw Pact states without consideration of their vital interest. Moreover, at that time Hungary, Czechoslovakia, and Bulgaria were also showing signs of interest in establishing diplomatic relations with the FRG. 39 Given the circumstances, there was a real danger that Bonn could gain influence in the Soviet bloc without conceding on any of the issues considered crucial to the security of Poland and East Germany. In the eyes of the Polish leaders, it was exactly what the KiesingerBrandt government in Bonn had hoped to achieve by undertaking its new Ostpolitik. 40 The danger was averted by almost frantic pressure from Gomulka and Ulbricht, which was reluctantly supported by Moscow, for a unified, tough, all-or-nothing approach to West Germany. Consequently, the Soviet leadership in early 1967 found it necessary to redefine the bloc's common German policy. 41

Nevertheless, the Polish sense of insecurity hightened even after the danger had passed. This was because of the initial soviet 
reluctance to react when Romania entered into diplomatic relations with the FRG. ${ }^{42}$ It reminded again the Polish leaders of another possibility of the Soviet-West German rapprochement, probably at the expense of East Germany. At an urgent meeting called probably at Polish insistence, the Poles expostulated that the vital interest of East Germany, and therefore their own, were in peril. ${ }^{43}$ Gomulka went as far as calling the Romanian policy "political diversion aimed at the liquidation of the German Democratic Republic. 44 To Gomulka, the Soviets were excessively underestimating the danger of West German penetration into Eastern Europe. The result of the fear on the part of the Poles and the East Germans was the chain of bilateral treaties on mutual friendship and assistance between East Germany on the one hand and Poland, Czecholsovakia, Hungary and Bulgaria, on the other. ${ }^{45}$ These treaties made any exchange of embassies with Bonn dependent on West Germarı recognition of East Germany's independent political status. ${ }^{46}$ Especially the treaty between Poland and the GDR should be seen as assurance against a possible deal between Moscow and Bonn.

The defensive solidarity between the GDR and Poland was again demonstrated during the crisis of Czechoslovakia. Both countries were most insistent among the Pact members in urging military intervention. In this case, too, Poland was uneasy about the Soviet stand on the issue, because of the fact that secret Soviet-West German diplomatic exchanges had been taking place on the agreement of renunciation of force. ${ }^{47}$ Moreover, in Prague, it was proposed that Czechoslovakia should embark upon an independent course in its relations with West Germany. 48 
The Polish leaders were also uneasy about the possible effect of Czechoslovak ferment on Poland's internal security. Furthermore, in the eyes of the Polish leaders Prague was about to accept a degree of West German economic and political penetration that would provide a direct strategic threat to Poland from the south. ${ }^{49}$ However, in spite of the Polish apprehension, the Czechoslovak crisis posed a fundamental threat to the Soviet Union, too. A new Czechoslovak-Romanian treaty of friendship and cooperation which was signed on August 16, 1968, and which limited the purpose of the Warsaw Pact to defense against NATO ${ }^{50}$, refueled the fear of the Soviet Union as well as of Poland and the GDR .

The Czechoslovak event underscored the danger of imperialist subversion and the need for unity among the Soviet bloc. ${ }^{51}$ It also induced the pact leaders to voice, even more strongly than before, the German threat. As was described by the Polish Prime Minister, Jozef Cyrankiewicz in his speech to the Sejm in April, 1968:

(The West Germans are) people who have not abjured their plans to wrest our lands and bury the independence of the Polish state, the same people... wantonly incite the overthrow of the German Democratic Republic, the same people who can see nothing ominous in the recrudescence of unabashedly nationalist, Fascist-leaning currents amid the West German community, its youth not excluded. 52

After the invasion, of Czechoslovakia, Moscow, in an attempt to make the German threat more credible, introduced the concept of "peaceful counter-revolution", allegedly a new, highly insidious tactic of the imperialists to mislead gullible people by arguing the necessity of "improving" socialism. 53 This concept was supported by authoritative Polish pronouncements and, most emphatically, by the 
East German leaders. ${ }^{54}$ They also launched an intensive propaganda offensive against liberal reforms. Attacking the Czechoslovak and in part the Yugoslav reforms, they contended that such measures inevitably would open a Commuist country to capitalist influences. 55 Thus, immediately after the military invasion of Czechoslovakia, there was . considerable tension between the two blocs. The intervention also led to a freeze of almost all East European initiatives for the CSCE. In spite of its extreme anti-West Germanism, which was strengthened especially since 1966 when Bonn attempted to improve its relations with the Warsaw Pact countries, Poland vigorously pursued diplomatic contacts in Western Europe, and also continued its efforts for arms reduction in Europe and for the CSCE. Warsaw's diplomatic efforts were culminated in September 1967, when General Charles de Gaulle visited Poland and was enthusiastically greeted by a traditionally Francophile population. However, the General's suggestion that Poland might play a more independent role outside the Soviet bloc was bluntly rebuked by Gomulka. ${ }^{56}$ The next month, Rapacki proposed that after the Non-Proliferation Treaty (Treaty on the Non-Proliferation of Nuclear Weapons) was signed, it would be appropriate to consider again establishing a nuclear freeze and then a denuclearized zone in Europe. Parallel to this, the equal reduction of conventional forces could be undertaken by national armed forces in the largest possible area of Europe, following which foreign troops stationed in the area could be reduced. 57 In May, 1968, in the midst of the Czechoslovak crisis, the Polish Institute of International Affairs (an unofficial body) released a major proposal for the CSCE project 
in sharply anti-American and anti-West German tones. The agenda of a CSCE, to be worked out by the countries concerned, should include "decisive" and not "marginal" issues, for example, recognition of existing European borders, renunciation of force, pan-European economic ties, and regional disarmament. Asserting that the Rapacki plans remained fully relevant, the proposal also advocated an agreed EastWest reduction of conventional armed forces, provided it did not change the military balance in Europe and was carried out under international control. The proposal also stated that a CSCE would help establish a healthier foundation for a European equilibrium by securing the acceptance of common principles of international cooperation and by eliminating artificial aspects of the continent's division. 58 By "artificial aspects of the continent's division", it meant Western nonrecognition of the postwar frontiers and Western political and economic discrimination against the Pact countries.

Poland's energetic campaign for the CSCE project notwithstanding, its strong emphasis on the anti-West German themes of the Conference greatly reduced the effectiveness of the effort. Furthermore, its close alliance with the GDR and to a limited extent with the USSR, as well as its leading role in the invasion of Czechoslovakia and the March Event of 1968 with its anti-Semitic tone, ${ }^{59}$ caused a sharp decline in Poland's image in Western Europe. These factors also limited the acceptability in the West of Poland's initiatives for the CSCE. 
NOTES FOR CHAPTER II

1 Multilateral preparatory talks of the CSCE lasted in Helsinki from November, 1972 to June, 1973. The first phase of the CSCE lasted in Helsinki from $3-7 \mathrm{July}, 1973$, the second phase in Geneva from September 1973 to July 1975. The final stage of the Conference took place in Helsinki from July 30 to August 1, 1975. On August 1, the ceremonial signing of the Final Act of the CSCE by the representatives of 35 states (including the United States and Canada) took place. For a detailed record of the whole conference including the preparation talks, see Luigi Vittorio Ferraris, (ed.), Report on a Negotiation: Helsinki-Geneva-Helsinki 1972-1975. (Alphen aan den Rijn, Geneva: Sijthoff \& Noordhoff International Publishers BV, 1979).

2 Polish Institute of International Affairs, Conference on Security and Cooperation in Europe: A Polish View, (Warsaw: Polish Scientific Publishers, 1976), p. 21.

3 The project was to establish a European nuclear striking force, with the European powers sharing with the United States in the control of atomic weapons. The plan, however, faced difficulties within NATO because some European powers had serious misgivings about the prospect of West Germany's having its finger near the atomic trigger. As to the origin and the development of this project, see Robert Hunter, Security in Europe, (Bloomington, Indiana: Indiana University Press, 1972), p. $105-110$. 
4

A. Ross Johnson, The Warsaw Pact's Campaign for "European Security", (Santa Monica, CA: RAND Corporation, R-565-pr, 1970), p. 6. The Soviet Union maintained an ambivalent attitude towards the U.S. role in the proposed conference. In the Bucharest Declaration of June 1966, it was stated, "There can be no doubt that the aims of a U. S. policy in Europe have nothing in common with the vital interests of the European peoples and the tasks of European Security," Ibid., p. 10. However, in late 1969, the Soviets agreed to the participation of the U.S. and Canada, because the NATO countries resolutely rejected the all-European Conference without the participation of the two countries. See Josef Korbel, Detente in Europe, (Princeton, New Jersey: Princeton University Press, 1972), p. $74-75$.

5 Johnson, op. cit., p. 6.

6 Ibid.

7 Ibid, p. 7 .

8 Mojmin Povolny, "The Soviet Union and the European Security Conference", Orbis, Spring, 1974, (p. 201 - 230), p. $203-204$.

9 Lawrence I. Whetten, "Recent changes in East European approaches to European Security", The World Today, July, 1970, (p. 277 - 288), p. 279 - 280. Whetten notes several reasons for Moscow's lack of enthusiasm in this period: 1) The Sino-Soviet dispute preoccupied the Soviet leaders up until November of 1965. By the spring of 1966, the attentions were so inverted that Moscow's freedom of maneuver had been sufficiently restored to allow engagement on other fronts. 2) By 1966 , the new Soviet leaders reversed the "hair-brained" schemes of their predecessor and attempted to place "peaceful co-existence" on a more 
credible basis. 3) With the erosion of Chinese pressure against Moscow, independent-minded Communist Parties recognized the limited leverage they could exercise in establishing mutualiy recognized autonomy within the world Communist movement. 4) Moscow viewed the West at that time as being in a state of acute crisis. Britain had been shut out of the Common Market, the multilateral nuclear force project died of its own weight, the U. S. was becoming increasingly preoccupied with non-European affairs (chiefly Vietnam), and a growing antagonism between the U. S. and individual partners (Turkey, France, and then Greece) was arising. President de Gaulle was asserting France's ascendancy as the chief spokesman of Western Europe, and his concept of a single European entity from the Atlantic to the Urals was to some extent compatible with the Communist idea of a single European security unit. Further, withdrawal of France from NATO's military wing marked what the Kremlin saw as a new erosion of U. S. leadership. 5) The difficulties of the Erhard regime, due partly to pressure from Washington, were regarded as providing a propitious moment to increase pressure against Bonn and its policy of integration with the West. 10 Lawrence L. Whetten, Germany's Ostpolitik: Relations between the Federal Republic and the Warsaw Pact Countries (London: Oxford University Press, 1971), p. 68.

11 Ibid.

12 Robert W. Dean, "Foreign Policy Perspectives and European Security: Poland and Czechoslovakia", in Robert D. Dean and Robert R. King (eds.), East European Perspectives on European Security and Cooperation, (Washington: Praeger, 1974), p. 127 - 128. 
13

Ibia.

14 Whetten, "Recent changes in East European approaches to European Security", 으. it., p. 278.

15 Johnson, op. cit., p. 8.

16 Ibia.

17 See the full text of the declaration in Hunter, op. cit., p. $239-247$.

18 Ibid. These measures are: 1) the abolition of military bases on foreign territories, 2) the withdrawal of all forces from foreign territories, 3) the reduction, on an agreed scale and at agreed deadlones, of the numerical strength of the armed forces of both German states, 4) the creation of a denuclearization zone, ard 5) the banning from European skies of foreign aircraft carrying nuclear weapons and from European parts of foreign vessels with nuclear weapons on board. 19 Ibid.

20 Karl E. Birnbaum, Peace in Europe: East-West Relations 1966 1968 and the Prospects for a European Settlement, (London: Oxford University Press, 1970), p. 48

Birnbaum notes that in contrast with adversary-partner relations between the Soviet Union and the U. S. before 1966, which had permitted mutual tacit restraint and even limited cooperation in spite of fundamental differences, the Soviets now put more stress on the adversary aspect than before. This was kecause Moscow was becoming more concerned about the growth of American military power and assertiveness and more aware of the opportunities opening up in some West European countries, as a result of the growing opposition to 
to American intervention in Vietnam. Therefore, the differentiated approach towards the West was the product of the Soviet intention to capitalize on the difference between Western Europe and the U. S. in order to decrease the latter's influence in European affairs.

21 Adam Ulam points out that this constituted a central feature of Moscow's conception of a detente. See Adam Ulam, "The USSR and Europe: the Destiny of Eastern Europe", Problems of Communism, January-February, $1974,(p .1-12), p .7$.

22 Ulam also points this out, "To be sure, detente with the West (and Western acknowledgement of the legitimacy and permanence of Soviet gains in Eastern Europe) would not be without certain risks and costs for the Soviet Union vis-a-vis the 'people's democracies', for it could conceivably weaken the Soviet position in Eastern Europe. After all, the threat of alleged 'German revanchism' had been a valuable Soviet asset in justifying the USSR's military presence and occasional intervention in the area, in securing the complete servility of the East German Communists, and in repressing any aspiration among the Poles and Czechs to follow Romania's, if not indeed Yugoslavia's path." Ulam, Ibid.

23 Korbel, op. cit., p. $71-72$. 24 Wolfgang Klaiber, "Security Priorities in Eastern Europe", Problems of Communism, May-June 1970, (p. $22-44)$, p. 35.

25 Robin Alison Remington, The Warsaw Pact: Case Studies in Communist Conflict Resolution, (Cambridge, Mass.: The M.I.T. Press, 1971), p. 90. The Soviet Union urged "the socialist countries to consider it their duty to render all possible support to the GDR, 
which is in the front lines of the struggle against the forces of militarism, and to further the strengthening of its positions and prestige."

26 Vaclav. L. Benes and Norman J. G. Pounds, Poland (New York:

Praeger Publishers, 1970), p. 135

27 Wladyslaw Gomulka, On the German Problem, (Warsaw: Ksiazka i Wiedza Publishers, 1969), p. 354 - 355.

28 For example, "the withdrawal of all forces (including Soviet) from foreign territories to within their national frontiers."

29 Korbel, op. cit., p. 74.

30 Nicholas Bethell, Gomulka: His Poland and His Communism, (Middlesex, England: Penguin Books, 1972), p. 238.

31

Ibid.

32 Neal Ascherson, "Poland's place in Europe", The World Today, December, 1969, (p. 520 - 529), p. 527.

33 Bethell, op. cit., p. 239.

34

Ibid.

35 Ibid., p. 240.

36 Ascherson points out yet another consequence of the Polish fear -- closer ties wïth France, noting, "...the third option -- the anchor in a third country -- was brought down from the shelf, if not effectively used: Poland set about cultivating General de Gaulle, a tactic which led to Mr. Cyrankiewicz's visit to Paris, and then to de Gaulle's astonishing tour of Poland in 1967. The Oder-Neisse frontier was reaffirmed by the French, but de Gaulle would not moderate his refusal to accept the legitimacy of East Germany." 
Ascherson, op. cit., p. 527 - 528.

37 It is important to remember that Poland's relations with the GDR were much less than friendly in 1958 when the Rapacki plan was given a "solemn state funeral". Stehle documents well the Polish leaders', especially Rapacki's disgust with East Germans. See Hensjakob Stehle, The Independent Sattellite, (New York: Praeger Publishers, 1965), p. 234. 38 Benes and Pounds referred to it as a "mariage de convenance", Benes and Pounds, op. cit., p. 376.

39 Birnbaum, op. cit., p. 59.

40 As to Gomulka's interpretation of Bonn's new policy, see Gomulka, op. cit., p. 356. "Bonn's new tactics provide for longrange action to attain these aims and for different ways of isolating the GDR from the Socialist states, for penetrating and undermining it from within."

41 Johnson, op. cit., p. 13.

42 Ascherson, op. cit., p. 528.

43 Ibid.

44 Benes and Pounds, op. cit., p. 375.

However, Romania hailed the establishment of diplomatic relations between Bonn and Bucharest as a major contribution to European security and international detente in the spirit of the Bucharest Declaration. See Birnbaum, op. cit., p. 60.

Gomulka countered by asserting that the main source of tension lay in Bonn. Therefore, the establishment of diplomatic relations between the Federal Republic and the socialist states would not contribute in any way to an improvement in the political climate of Europe 
unless there was a concomitant change in the basic West German position relating to the vital interests of the socialist countries. By vital interests of the socialist countries, Gomulka unambiguously referred to Bonn's recognition of the Oder-Neisse and East Germany Ibid., p. 61

45 The dates of these agreements are March 15, March 17, May 18, and September 7, 1967, respectively.

46 Besides, the parties acknowledged the existence of two German states, emphasized the inviolability of present frontiers, and promised to defend one another in the event of aggression. West Berlin was said to be a separate political unit on East German territory. The parties agreed to consult with each other on all important international questions (in this context meaning the question of relations with West Germany). Out of this web of treaties emerged the so-called "Ulbricht doctrine". The GDR, before March 1967, had a bilateral treaty only with the Soviet Union (of June 1964).

47 Birnbaum, op. cit., p. 83.

48

Ibid., p. 80.

49 Ascherson, op. cit., p. 528.

50 Whetten, Germany's Ostpolitik, op. cit., p. 51.

51 For instance, Gomulka argued on September 8, "The Warsaw Pact nations have the right of self-defense when the enemy mines our own house, the community of socialist states, with dynamite." Quoted by Harlan Cleveland, "NATO after invasion", Foreign Affairs, January, $1969,(p .244-257)$, p. 252.

52 Benes and Pounds, op. cit., p. 377. 
53 Birnbaum, op. cit., p. $86-87$

54

Ibid.

55 Klaiber, op. cit., p. 41.

56 M. K. Dziewanovski, "Poland's International Position under Gomulka and Gierek", in George W. Simmonds (ed.), Nationalism in the USSR \& Eastern Europe, (Detroit: The University of Detroit Press, 1977), p. 355 .

57 Johnson, op. cit., p. 17.

58 Ibid., p. 19.

59 As to the complexity of the March event, see the detailed account by A. Ross Johnson, "Poland: End of an Era?", Problems of Communism, January-February, 1970, (p. $28-40)$. 
CHAPTER III

POLISH-WEST GERMAN RELATIONS -- A KEY TO THE CSCE?

On 7 th December, 1970, the treaty on the bases for normalizing relations between Poland and the FRG was signed in Warsaw after long and difficult negotiations. Next to the Moscow treaty between the USSR and the FRG -- it constituted an important step forward to removing the remnants of the cold war, eliminating one of the main sources of tension, strengthening the detente and stabilization processes in Europe and making the holding of a European conferenee possible..

The visit (of Chancellor Willy Brandt) was tremendously moving both for the participants and for the millions of Poles and Germans who followed it on their television screens. Some of the scenes almost defied description. Here was a head of the West German Government, with a great-grandson of the Iron Chancellor, Klaus von Bismark, a leading Polonophile, at his side, putting his signature to a decument that solemnly renounced his country's right to some 40,000 square miles of what had been the fruit of centuries of Teutonic conquest in the East. Here was a German Chancellor kneeling in prayer at a memorial for half a million Jewish victims of the Warsaw ghetto, slaughtered by his Nazi compatriots. What unforgettable historic movie scenes!?

Indeed, the Bonn-Warsaw treaty had a significant impact on Poland's position both in the West and in the East. In the West, as mentioned above, Poland's uncompromising position on the German problem and its unabated anti-West German slogans greatly deteriorated its image there, thus impeding its efforts to cultivate better relations with the West European countries. But now that it gained de facto recognition of the Oder-Neisse frontiers, ${ }^{3}$ the hindrance was largely cleared. The time had arrived for Poland when it could proceed to develop close ties with the West with a strong backup of 
the CSCE project. The embodiment of the CSCE was, in turn, to grant Poland multilateral recognition of its Western borders. Furthermore, the Warsaw treaty significantly raised Poland's status within the Soviet bloc in the sense that the normalization of relations with the FRG emancipated Poland from its political debtor status in the Pact. It also emancipated Poland from its "Rapallo" psychosis to a large extent. ${ }^{4}$ Before the Warsaw treaty, Poland had to depend upon Moscow's "good will" for the protection of its western territories. This debtor status strictly limited Warsaw's influence over the Pact's decision-making procedures.

Moreover, as Dziewanowski describes it accurately, the treaty had immense psychological consequences on the average Pole. With the fear of a German bogey removed and Poland's subordinate position in the Soviet bloc largely overcome, the Poles became more self-assertive about their national interests. This could have reminded the Soviet leaders of the "Romanian syndrome".

What, then, caused this volte-face of Polish foreign policy? Back in 1955, following the Soviet offer to establish diplomatic relations with the FRG, Poland followed suit. On January 31, 1955 it declared that it was contemplating the normilazation of relations with the FRG. The Polish Prime Minister, J. Cyrankiewicz, restated the Polish willingness to do so on March 16, 1955, and again on July 6 . Boleslaw Bierut, the First Secretary of the Polish Party did the same. ${ }^{5}$ The offers were not accompanied by any precondition, specifically the recognition of the Oder-Neisse frontier. In June, 1957, after the October revolution in Poland, Gomulka reiterated his willingness to 
establish diplomatic relations without any preconditions. 6

However, the then Adenauer government repeatedly turned down the offers. The reason for Bonn's refusal was twofold: 1) Given Polish official ties to the GDR, to establish diplomatic relations with Poland would have undermined the FRG's claim to be the only legitimate government of the entire German people, 2) it would have also been interpreted, both domestically and internationally, as a de facto recognition of the Oder-Neisse. Thus, since the Hallstein doctrine was formulated in late 1955, the Polish offers for diplomatic relations were considered by Bonn as a challenge to the doctrine. To further discourage Polish willingness, the West German Foreign Minister, Heinrich von Brentano confirmed, in June 1956, that Bonn did not intend to establish diplomatic relations with the East European states, and that Germany existed legally within the 1937 frontiers and would not recognize any frontier modifications which had taken place since the war. 7

In the fall of 1957, Gomulka stiffened his attitude and stated that Poland would establish diplomatic relations with the FRG only if the FRG would recognize the Oder-Neisse frontier. 8 Together with the Hallstein doctrine, this Polish move created a stalemate for PolishWest German relations in the years to come. 9 However, in spite of the deadlock on the diplomatic front, some progress was made in the economic sphere. After 1956 the annual trade agreements were concluded between the two countries and Bonn made available a yearly rotating credit to facilitate German exports to Poland. 10

By the latter part of the Erhard administration, one could detect 
a significant change in the attitude of the West Germans. While in 1951 almost every West German rejected the idea of accepting the OderNeisse frontier, in 1967, almost half were resigned to it. ${ }^{11}$ This in part explained the Foreign Minister Gerhard Schroeder's more flexible eastern policy. In 1965, Schroeder declared the West German intention to normalize relations with Poland "without surrendering vital German interests." 12 He also made it clear that Bonn's policy toward the individual East European states would be differentiated, meaning that the FRG intended to improve its relations with some of those states more than with others. ${ }^{13}$ This statement alarmed the Polish leaders. It implied to them the prospect of some kind of secret deal between Bonn and Moscow at the expense of East Germany. ${ }^{14}$ This differentiated approach was considered in Warsaw as an attempt to disunify the Warsaw Pact's common policy toward the FRG. In 1966, Bonn offered to exchange with Poland, the Soviet Union, Czechoslovakia and the other Warsaw Pact states except the GDR, declarations of mutual renunciation of threat or use of force for the settlement of disputed questions. ${ }^{15}$ The proposal was immediately rejected precisely because the acceptance of Bonn's proposal would have isolated the GDR.

Furthermore, the Warsaw Pact's Political Consultative Committee which met in Bucharest in July of.1966, launched the Pact's major campaign for the CSCE, and attempted to redefine the Pact's anti-West German policy. Thus during this period there was little prospect of improving relations between Warsaw and Bonn. Moreover, the price of establishing diplomatic ties was inflated still further in 1966 with Warsaw adding two more conditions: a categorical renunciation of nuclear 
weapons and the recognition by Bonn of the GDR. ${ }^{16}$ By deliberately linking the issue of a Polish-West German reconciliation to the West German recognition of East Germany, which was clearly incompatible with the policy objectives of the FRG, Warsaw postponed the prospects of reconciliation indefinitely. But the level of Polish-West German trade had risen gradually, since the West German trade mission was established in Warsaw in 1963, and reached an annual turnover of approximately one billion marks in $1966 .{ }^{17}$

At this point of stalemate, the Grand Coalition which took power in Bonn in November 1966 "Ieft the trenches of the Cold War." 18 This government was led by Chancellor Kurt G. Kiesinger (Christian Democrats) and the foreign minister and vice Chancellor Willy Brandt (Social Democrats), and controlled 447 of the 496 Bundestag votes. ${ }^{19}$ In contrast with the previous administration, which tried to exclude the GDR from its dealings with Eastern Europe, the Grand Coalition tried to include the GDR, for example, in the renunciation of force agreements. As to Poland, Brandt expressed the importance of good relations between them, equated Poland with France in the West, and held that a reconciliation with Poland was their moral and political duty. ${ }^{20}$ He also was well prepared to recognize the existing borders for the period for which the FRG could commit itself, i.e., until a peace settlement. ${ }^{21}$ However, the West German leaders had to face continuous disappointment in Warsaw's responses. The Polish leaders ostentatiously demonstrated their support for Pankow and increased the extent of the anti-West German campaign. This was especially true after Bonn established diplomatic relations with Bucharest, as well as during and after the 
Czechoslovak crisis. Gomulka denounced Bonn's new Ostpolitik as a measure tha't was deliberately conceived in order to divide and overcome the socialist states in Eastern Europe one by one. ${ }^{22}$ Furthermore, he placed as Bonn's second highest goal the overthrow of Poland's western frontier by force in the following speech he gave in September 8, 1968:

Have we any grounds to speak of the danger of an armed attack on Poland, of the enemy's intention to change our state frontiers? Unfortunately we have. Since the foundation of the German Federal Republic almost every day has given us irrefutable proof of this. The whole world knows that one of the foremost aims of the policy of all West German governments was and still is to destroy the existing Polish state frontiers and to incorporate one-third of the territory of the Polish state into Germany. In the hierarchy of the aims of Bonn's policy the destruction of Poland's frontiers on the Odra, Nysa and the Baltic takes, of necessity, the second place. Bonn's first, foremost aim is to liquidate and swallow up the German Democratic Republic. There is no need to explain that these aims of West German policy are accompanied by war plans. 23

Finally, at the Fifth Congress of the Polish United Worker's Party in November 1968, three more preconditions were added for the normalization of relations with the FRG in addition to the already demanded recognition of the Oder-Neisse and of East Germany, and Bonn's categorical renunciation of nuclear weapons. These preconditions were Bonn's declaration of the Munich Agreement as invalid ad initio, renunciation of any claims to West Berlin, and renunciation of claims to representation of the entire nations. ${ }^{24}$ Gomulka also argued that these preconditions were in line with the basic premises of allEuropean security, i.e., recognition of the status quo. ${ }^{25}$ Furthermore, at the turn of 1969 there was a noticeable increase in the exchange of delegations between Warsaw and Pankow. There were also indications of 
the two countries' efforts to coordinate their propaganda activities more closely. ${ }^{26}$ During the same period, the Polish leaders displayed heightened interest in the GDR's economic mechanism. In January 1969, the Polish United Workers' Party Politburo members Boleslaw Jaszczuk and Edward Giered led a high-powered economic delegation to East Berlin with the stated purpose of studying its economy. These contacts culminated with the visit of Gomulka and Cyrankiewicz to Pankow in April. ${ }^{27}$ The joint communique issued upon the conclusion of the visit proclaimed the "complete unanimity" of the two sides on all questions. Thus in the spring of 1969 no one expected that Warsaw's overture for PolishWest German reconciliation was forthcoming. However, to the surprise of many, on May 17, Gomulka gave the following speech:

For some time now trends have been appearing in definite quarters in the German Federal Republic which seem to indicate intentions slightly different (in) programming Bonn's Eastern policy.... I have in mind first of all certain statements by the leaders of the West German Social Democratic Party at its congresses in Nuremberg and Bad Godesberg as well as other public declarations, especially those made by the FRG ViceChancellor, Mr. Brandt....The position of Chancellor Kiesinger vis-a-vis the question of frontiers...has not changed to this day...Representatives of the Social Democratic Party in that government take their own position on certain important matters of Bonn politics; the latter (position) does not fully correspond to the position of their coalition partners.

There are...signs of differences of view on the question of the FRG's attitude towards the German Democratic Republic and on the problem of Bonn's Eastern policy... Chancellor Kiesinger did not confirm the formula of the Minister of Foreign Affairs and Vice-Chancellor of his government on the recognition of existing frontiers in Europe. In fact, the formula has been repeated only by the SPD members of the coalition government. One should not underrate the fact that from a political point of view the Nuremberg SPD formula on the recognition by the FRG of the Oder-Neisse frontier represents a step forward if compared to the position expressed on the subject by all the FRG governments. At the same time we have to realize fully that every interstate agreement between Poland and the 
FRG if based on that formula, even under its most favorable interpretation for us, could not contain more than a recognition of the Oder-Neisse frontier by the FRG and only a temporary one, i.e., until a peace treaty with Germany is concluded. Therefore, assuming even that the Bonn government should adopt the Nuremberg formula of Vice-Chancellor Brandt, this would actually change nothing in the present state of affairs. A change can only come about if the FRG government unreservedly recognizes the existing frontier of Poland on the Oder-Neisse frontier which would depart from the Zgorzelec (Gorlitz) Treaty concluded with the German Democratic Republic.... If West Germany. wishes to coexist peacefully with other European countries...(this) requires recognition of the borders established as a result of the Second World War, including in the first place the OderLustian-Neisse frontier, renunciation by the FRG government of the illegal claims to exclisive representation of the German people, i.e., recognition of the other German state, the GDR, and signing of the treaty on non-proliferation of nuclear weapons. 29

In this speech, Gomulka still reasserted the demands for renunciation of nuclear weapons by Bonn and recognition of East Germany as well as other preconditions, but they were given little emphasis in comparison with his stress on the need to settle the territorial dispute between the two countries. 30 The Nuremberg SPD formula was singled out as a positive indication of growing reasonableness in West German politics. 31 Even though Gomulka characterized the formula as unsatisfactory because of its provisional nature, he called for the normalization of relations between the two countries. Furthermore, he explicitly invited Bonn to enter into negotiations to conclude a treaty similar to that which had been signed between Poland and East Germany in Zgorzelec, 1950, which would provide de facto recognition of the Oder-Neisse frontier. 32

But in the same speech, before he made a proposal for a border agreement, Gomulka reiterated the recent Budapest appeal to convene a general European conference on security and cooperation. He also 
reasserted that the concept of the CSCE, "remains in full accord with proposals which Poland has in fact been submitting over the last five years. 33 "Only in conditions of a strengthened sense of security", Gomulka went on, "could the division of Europe into two opposing military groups be overcome. ${ }^{34}$ The socialist states were ready to open a dialogue with every state showing interest in the CSCE initiative. The Polish leader was prepared to discuss any constructive proposal for the all-European Conference, "no matter where it might originate from."35 Thus, Gomulka attempted to give an impression that Warsaw's overture of peace to Bonn was an essential part of the overall Warsaw Pact's campaign for the CSCE. It therefore, should be viewed as a major contribution to the coordinated bloc policy. 36

However, the reasons why this dramatic shift of Polish foreign policy took place have not been answered. One of the reasons was obviously the Polish "Rapallo psychosis" -- distrust of a Soviet-West German rapprochement reached over the Poles' heads. The resumption of low-level diplomatic contacts between Bonn and Moscow as early as late 1968, and early 1969 was detected in Warsaw. 37 This made the Polish leaders greatly suspicious of Soviet intention toward West Germany, exactly as it had happened in 1964. In the eyes of the Polish leaders, the Soviets, faced by the worsening of Sino-Soviet relations, might have sought some cheaper ways to stabilize Europe -- reconciliation with the FRG without its recognition of the Oder-Neisse and East Germany.

Secondly, the shift could be explained by economic motives. By the second half of 1968, the Polish economy was in the throes of 
yet another of its periodic crises. At the Fifth Congress held in Warsak in mid-November, 1968, economic reform was discussed as the main topic and the plans for industrial modernization were set forth. 38 In April 1969, a month before Gomulka's May speech, he made a series of striking admissions of mistakes committed during the 1966-1970 plan. 39 State enterprises had all too frequently been exceeding their investment quotas, he said, and too often original estimates of necessary financial outlay had turned out to be badly calculated. It was also suggested that home comsumption be cut, especially of food, in order to leave more money available for export to buy the Western machinery so necessary for Poland's industry. ${ }^{40}$ In the spring of 1969, however, the Polish leaders had reason to believe that, if Poland could normalize its relations with the FRG, Bonn might help Poland towards her economic break-through with a massive loan. Warsaw was full of stories that West Germany was ready to advance 500 million dollars on favorable terms, and already officials of ministries were meeting and working out how the huge sum should be distributed. ${ }^{41}$ Dr. Berthold Beitz, a director of Krupp, was also visiting Poland and discussing ways in which his vast firm could help develop the country. 42

Thirdly, beyond the facade of friendship and unity, WarsawPankow solidarity was being untied. Amid signs of increasing economic difficulties in Poland since 1968, particularly in the investment field, the Polish leadership had apparently counted heavily on East German assistance for the modernization of Polish industry. Assistance was expected in their bilateral relations as well as within the frame- 
work of the closer CMEA integration, of which both Poland and the GDR were once the principal proponents. ${ }^{43}$ However, in early 1969, there were reports that East Germany had refused to grant a Polish request for a large loan. 44 Moreover, the GDR moved away from its former strong support of closer economic ties within CMEA. In a meeting in Moscow in April 1969, the GDR reportedly ranked with Romania as the strongest opponent of any kind of CMEA integration. ${ }^{45}$ Another contention related to this was the fact that the GDR had been substantially benefiting from its special relationship with both West Germany and the Soviet Union, since West Germany treated trade with the GDR as internal trade. ${ }^{46}$ Moreover, despite its privileged economic status, Pankow had been adamantly cautioning its allies against the dangers of West German economic penetration in Eastern Europe. 47 This, too, made the Poles seriously question the wisdom of close Polish-East German solidarity .

Fourth, since the mid-60's, domestically, Gomulka had been under increasingly heavy pressure from various quarters to consider the changing political atmosphere in West Germany and to mitigate his hard stand vis-a-vis that country. The first open pressure came from the Polish Catholics. As early as 1962, the influential Catholic writers observed positive changes in West Germany. In 1965, the Polish episcopate came out with a letter calling for a reconciliation between the two nations in a true Christian spirit. ${ }^{48}$ The letter was received warmly by the German Catholics. Opposition to Gomulka's anti-West Germanism also came from within the Polish United Worker's Party. Many younger, better educated, and more open-minded members of 
the Party felt that Gomulka's policy was not only sterile, but was in

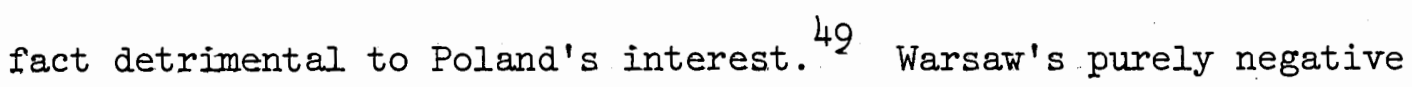
posture toward Bonn discouraged the elements striving for a genuine reconciliation and played into the hands of the hard liners in the FRG. Fifth, the shift might have been in part motivated by the desire to influence the West German elections in September, 1969. From the viewpoint of the Poles, Brandt's assession to the Federal Chancellory would increase the likelihood of recognition of the Oder-Neisse. This hope was certainly supported by Brandt's earlier statements on the necessity of reconciliation with Poland, which he equated with Bonn's reconciliation with France. ${ }^{50}$ However, in view of the fact that, as of 1967 almost half of the West German population was willing to recognize the Oder-Neisse boundary, ${ }^{51}$ it seemed Gomulka's May speech had little impact on the outcome of the elections. Moreover, Poland's too friendly attitude towards the Social Democrats could have given the West German conservatives a rationale to claim that Brandt was well received in the Soviet bloc because he conceded a great deal of vital West German interests.

Last, but the most important in the context of this paper, the complete about-face in Polish foreign policy was caused by the obvious failure to achieve Poland's most important objective -- multilateral recognition of its western border. Because of its uncompromising attitude toward West Germany, Poland's call for the all-European conference, through which Poland was to gain multilateral recognition of the boundary, was far from convincing. The Western powers became skeptical of the CSCE project because of Poland's (and East Germany's) 
excessive emphasis on the anti-West German themes of the proposed conference. Its close alliance with East Germany, more specifically making recognition of the GDR one of the preconditions for Bonn-Warsaw rapprochement, stood in the way of improving Poland's relations with other western countries, thus seriously restricting its scope of maneuver in the international sphere. Furthermore, as mentioned above, Poland's intense anti-West German propaganda was obviously counterproductive since it hurt Poland's image much more than that of the FRG. Thus, continuation of the Warsaw-Pankow "axis" meant that Poland would remain forever on the sidelines of international developments and would be denied playing any constructive role in advancing the EastWest detente.

This is the background against which Gomulka's overture should be viewed. It was a significant departure from a defensive and reactive foreign policy, to a much more self-assertive, active foreign policy. His speech signified, by abandoning its former shells, a demarcation between Polish national interests and the interests of other Pact members, particularly East Germany's. By decoupling its national interests from those of the GDR, Poland was emancipating itself from the East German veto power in its major foreign policy considerations. However, this reassertion of a more independent foreign policy met, as had been expected, strong East German objection. In the eyes of the East German leaders, Gomulka's May speech was reminiscent of the establishment of diplomatic ties between Bonn and Bucharest in January: 1967, which was considered a treachery not only by the GDR but also by Poland. 
sell-out of their vital interests as a result of the Bonn-Warsaw rapprochement reached over their heads. This fear was reinforced by the fact that Warsaw's overture was preceded by negotiations between Bonn and Moscow. Thus, the East German version of the Rappalo psychosis was doubled. Even though Gomulka's more flexible stand toward the FRG was warmly received by Brandt, an official East German newspaper Neues Deutschland gave a distorted account of Brandt's view. 52 The article was entitled "Brandt opposes relaxation," which was the exact opposite of the truth. ${ }^{53}$ They also stepped up their hostility toward the SPD leaders by calling them "lackeys of West German imperialism," 54 and maintained that the SPD Ministers in the Bonn government were "serving as a Trojan horse for the attempted promotion of the counterrevolution in Eastern Europe. $" 55$ The East German indignation over Poland's altered position was openly confirmed in the speech given in Warsaw in July, 1969, by the East German Premier, Willi Stoph. Ignoring Gomulka's proposal to the FRG to recognize Poland's western frontier, the East German leader insisted that the security of the Oder-Neisse border was inseparably linked with the maintenance of the Elbe-Werra line. 56

As seen in the East German reaction, for example, Warsaw's drastically new approach towards the FRG left the Polish leadership open to the charge of violating the common Pact's positions vis-a-vis that country. To put it another way, the shift would be interpreted as a measure designed only to further Polish national interests. Here, Poland countered by invoking the Warsaw Pact's common interest in holding an all-European conference. Warsaw claimed that it was 
necessary to make overtures if Bonn were ever to be brought to the conference table. Thus, in proposing the border treaty with West Germany, Gomulka linked it directly with the CSCE project. Prime Minister Cyrankiewicz, explaining the initiative to the Sejm in June, proclaimed that Gomulka's May 17 proposal had been made "on the basis of the Budapest Appeal, in the name of European Security, and not only in the name of directly Polish interests." 57 In early 1970, Gomulka again reiterated that the border treaty proposal was to be viewed as part of the East-West European dialogue to prepare for the CSCE. 58

To be sure, the Budapest Appeal partly induced the Polish leadership to take a more flexible attitude toward the FRG. Compared with the Bucharest Appeal of 1966 and the Karlovy Vary declaration, the Budapest Appeal was characterized by its mild tone and vagueness. (See Chapter II). The decreased hostility toward the FRG and the United States contained in the appeal was significant in the sense that it reflected to a limited extent the altered Soviet stance toward the CSCE project as well as West Germany. This speculation was strongly supported by the fact that the Budapest meeting was preceded by semisecret negotiations between Moscow and Bonn. Romanian rebellion within the Pact notwithstanding, it was probably the Soviet leadership itself which decided to relaunch the CSCE project with less emphasis on preconditions and a decreased level of invective against the Western powers than in the past. It seemed that this altered Soviet position vis-avis the FRG and the CSCE project was perceived quite accurately in Warsaw. As discussed above, the Soviet overtures to West Germany caused the Rapallo psychosis among the Polish leadership only when 
Poland could not follow suit. Nonetheless, when Poland could manage to follow suit, as it did in May 1969, the Soviet approach was properly interpreted in Warsaw as a green light for its rapprochement with Bonn. In May 1969, Poland witnessed favorable developments within the FRG concerning the recognition of the Oder-Neisse and the strong support of the CSCE project.

Thus, Poland attempted to achieve through the CSCE what Rapacki had attempted to achieve through his "constructive coexistence" and the various Rapacki plans; the relaxation of tension between the two camps, establishment of closer economic and cultural ties between Poland and the West, upholding the role of the small-medium sized states, and Poland's more independent foreign policy. Accordingly, from late 1969, Poland's new foreign policy orientation was manifested by a revived diplomatic offensive towards various Western European capitals. Poland soon emerged as a major proponent of the CSCE. These efforts proved to be more effective mainly because of a termination of Poland's anti-West German propaganda campaign.

Within the Warsaw Pact, too, Poland soon became the chief proponent of discussing regional arms control and disarmament measures at the CSCE, and seemed to have actively lobbied in Warsaw Pact councils to this end. It also reasserted the continued relevance of the Rapacki plans for a nuclear weapons freeze or a denuclearized zone in Central Europe and spoke of the desirability of a regional complement to the Non-Proliferation Treaty. Furthermore, Poland placed new stress on the issue of disarmament and regional arms control through its delegate to the U. N. Committee on Disarmament in Geneva. 59 
The treaty providing for the acceptance by the FRG of the Polish western boundary and the establishment of diplomatic relations between the two countries was signed on December 7, 1970. Two weeks later, after the worker's rebellion in the costal cities, Gomulka resigned as First Secretary and was replaced by Edward Gierek, In spite of their preoccupation with the domestic crisis the new Polish leaders did not neglect foreign relations. Immediately after coming to power, Gierek emphasized continuity in Poland's foreign policy started by Gomulka in 1969.60 It seemed, the momentum acquired through the CSCE project was not only maintained but was accelerated, and earlier initiatives took on new dynamism. In the early $70^{\prime} \mathrm{s}$ Polish diplomacy was at the height of its activity in the post-war period.

Poland's relations with West European countries were greatly expanded. In October of 1971 an agreement was made for the mass production of small-Fiat cars in Poland, and in November a protocal guaranteeing Poland long-term Italian credits was signed. 61 In spite of Britain's reserved attitude toward the CSCE, economic cooperation between the two countries continued to progress. In the winter of 1971, an agreement for a Polish-British venture in coproduction of machine tools was concluded, followed in the summer by a contract with the British Petroleum Company for joint construction of an oil refinery at Gdansk. In mid-June of the same year, Foreign Minister Stefan Olszowski visited Austria. A month later an agreement to abolish visas between the two countries was signed. 62

Especially good relations were developed with the Scandinavian countries. At the end of June 1972, the Polish Foreign Minister went 
to Oslo and in October, Premier Piotr Jaroszewicz visited Stockholm. Tourism between Poland and Sweden was to be facilitated and the Swedes were to build a luxury hotel in Warsaw. The Finns had been in close consultation with the Poles on preparations for the Conference on Security and Cooperation in Europe. Early in 1972 a senior Polish diplomat, Adam Willman, obviously with the prospect of the Conference being held there, was appointed Ambassador in Helsinki. ${ }^{63}$ At the same time informal contacts aimed at promoting the CSCE were intensified. Foreign diplomats, scholars and journalists were invited to discussions by the Polish Institute of International Affairs, round tables were organized, and Western views on European problems were published in the Polish press. 64

Polish-American relations, however, improved even more significantly in this period. The cold atmosphere between the two countries which prevailed in the latter Gomulka years was overcome. In the spring of 1971 two high level Polish missions, headed by the Minister of Chemical Industry and the chairman of the Committee of Science and Technology respectively, visited the United States. Later that year, Gierek expressed interest in increasing trade and in obtaining technological information from the United States, who responded positively. In August, 1971, the U. S. granted Poland an export license for the purchase of a catalytic cracking plant. ${ }^{65}$ In October small credit to finance the purchase of American agricultural products by Poland was offered. In early 1972, the Polish officials often emphasized the importance in expanding economic, scientific and technical relations between the two countries. In turn, President Nixon expressed a 
positive view on the betterment of relations with Poland. 66 The improvement of the relations between the two countries was symbolized when President Nixon stopped over in Warsaw on his way back from Moscow on May 31, 1972. During the two meetings the President had with the Polish leaders, various accords were reached. In bilateral relations it was agreed to hold regular consultations to develop trade and to expand scientific cooperation. Moreover, a consular agreement clarifying the status of Polish-Americans was signed. Nixon also extended an invitation to Gierek and Jaroszewicz to visit the United States. 67

As shown above, since 1969, there had been an upsurge of activity in Poland's diplomatic relations. This was seen in Moscow yet not without apprehension. Moscow suspected a similar enthusiasm in Polish foreign policy as it had found in that of Czechoslovakia in 1968. However, Poland's aggressive foreign policy was formulated in the name of the CSCE and as a contribution to, as well as preparations for that Conference, which the Soviet Union itself had also wanted. In this sense Poland's more self-assertive foreign policy was not only compatible with the Pact's interest but it, if it was successful, would also uphold its status in the Soviet bloc, which would, in turn, bolster the effectiveness of the Polish foreign policy in the West. 
NOTES FOR CHAPTER III

1 Polish Institute on International Affairs, Conference on Security and Cooperation in Europe: A Polish View, (Warsaw: Polish Scientific Publishers, 1976) p. 28.

The negotiation on the normalization treaty between Bonn and Warsaw started on February 5, 1970. It was signed by both parties on December 7, 1970. After a long debate in West Germany, the treaty was ratified by Bonn in May, 1972, and by Warsaw the same month.

2 M. K. Dziewanowski, "Poland's International Position under Gomulka and Gierek", in George W. Simmonds (ed.), Nationalism in the USSR \& Eastern Europe, (Detroit, Michigan: The University of Detroit Press, 1977) p. 355-356.

3 As to the difference between de facto recognition and de jure recognition, as well as to the difference between West German and Polish interpretation of the treaty regarding the Oder-Neisse border, see W. W. Kulski, Germany ana Poland: From War to Peaceful Relations, (New York: Syracuse University Press, 1976) p. 188-198. Lawrence L. Whetten, Germany's Ostpolitik: Relations between the Federal Republic and the Warsaw Pact Countries. (London: Oxford University Press, 1971) p. 151 - 166, also Keesing's Research Report, Germany and Eastern Europe Since 1945: From the Potsdam Agreement to Chancellor Brandt's Ostpolitik, (New York: Charles Scribner's Sons, 1973) p. 272296. Article 4 of the treaty states that the treaty does not affect the validity of both parties' previous bilateral and multilateral 
international agreements. This subordinated the normalization treaty to the Potsdam and Paris Agreement, thus upholding the Allies' reservations about the final disposition of the territorial claims. Therefore, West Germany recognized the Oder-Neisse frontier only on its own behalf and only for the duration of its existence. The West German commitment was not to bind a reunified Germany. However, by Article 1 of the treaty, Bonn would be forbidden from raising territorial claims against Poland at the peace conference.

4 It was seen during the long negotiation between Warsaw and Bonn. Poland's anxieties increased as the Bonn-Moscow negotiations proceeded at a faster pace. See Whetten, op. cit., p. 119.

5 Kulski, op. cit., p. 112.

6 He renewed the offer stating:

"Without going into matters of the political system of the German Federal Republic, we are prepared to conduct a mutually advantageous economic and cultural exchange and generally maintain normal relations with her, based on the principle of peaceful coexistence." Quoted in Alfons Klafkowski, The Polish-German Frontier After World War II, translated by Edward Rothert, (Poznan: Wydawnictwo Poznanskie, 1972) p. 9.

7 Kuzski, op. cit., p. 111.

8 Ibid., p. 112 .

9 The West German objection to the Rapacki Plan also contributed to the deterioration of relations between Warsaw and Bonn. Moreover, together with the "Strauss Law" (see note 34, Chap. 1), Bönn's strong objection to a nuclear-free zone was interpreted in Warsaw as 
Bonn's strong determination to get access to nuclear arms, thus refueling the Poles' fear of West Germany. In November, 1958 Gomulka spoke about the West German rejection of the Rapacki Plan and stated, "Of all the governments (Bonn) was the one that protested most vehemently against the Polish proposal to create an atom-free zone in Europe, in spite of the fact that exclusion of German territory from the effects of those horrible weapons is in the most vital interests of the German nation itself." Gomulka went on, "Bonn has reacted in a similar way to the Polish government's recent additional explanations to this plan (i.e. the second Rapacki Plan), which were yet another expression of the good will of Poland." Wladyslaw Gomulka , On the German Problem (Warsaw: Ksiazka i Wiedza Publishers, 1969) p. 129.

10 Adam Bromke, Poland: The Last Decade, (Ontario: Mosaic Press, 1981) p. 119.

II John H. Herz, The Government of Germany, (New York: Harcourt Brace Jovanovich, Inc., 1972, Second Edition) p. 177. In this transformation of opinion the German Church played an important role. In October, 1965, a widely discussed memorandum of the Evangelical Church of Germany challenged the "right of homeland" thesis of German expellees, because it clashed with similar rights of the Polish residents who had been born in the Polish western territories. For an excellent discussion on the role of the Church, see Laszlo Gorgey, Bonn's Eastern Policy: 1964-1971, (New York: Anchor Books, 1972), p. 31-40. 
12

Whetten, op. cit., p. 17 .

13

Kulski, op. cit., p. 126.

This new policy to secure concessions from the Warsaw Pact countries "collectively if possible, individually if necessary", was considered in Moscow as an unfriendly move which ignored the Moscow's rule over Eastern Europe. It challenged the Soviet thesis, "The road to Bonn runs through Moscow."

14 The East Germans were particularly bothered by Bonn's new approach and made no secret of the fact that they saw in the new approach a threat to communism: "Schroeder thinks that the exchange of official trade missions between West Germany and some people's democracies is a particularly cunning move. Its aim is to restore active contacts by the Bonn Government which had isolated itself from the majority of socialist countries by its Hallstein Doctrine and its demand for revision of the existing borders. Connected with it is the illusion of being able to weaken the close relations of the GDR with some people's democracies, firstly economic and later by other means..." Neues Deutschland, April 16, 1964, cited in Zbigniew K. Brzezinski, Alternative to Partition. (New York: Mcgraw-Hill Book Company, 1965) p. 96

15 Kulski, op. cit., p. 126.

16 Bromke, op. cit., p. 119.

17 R. F. Leslie, (ed.) The History of Poland since 1863,

(London: Cambridge University Press, 1980) p. 382.

In March, 1963, a three-year trade agreement was concluded between the two countries. During the same period, Poland concluded a trade agreement with France, and the existing Anglo-Polish one was extended. 
18 Theo Sommer, "Bonn Changes Course", Foreign Affairs, April, 1967, (p. 477-491) p. 488.

Sommer notes that the Grand Coalition, "has scrapped the old concept that reunification must precede detente, as well as the philosophy that any step toward relaxation of tension in Europe must be linked with a step toward German unity."

19 Herz, op. cit., p. 171.

20 Willy Brandt, A Peace Policy for Europe, (New York: Holt, Rinehart and Wilson, 1968) p. 152.

21 Willy Brandt, "German Policy toward the East", Foreign Affairs, April, 1968 (p. 476-486) p. 484.

22 Gomulka in the same speech also claimed that Bonn's new Ostpolitik was merely new methods applied to an old policy which attempted to "isolate the German Democratic Republic, to tear it away from the Warsaw Treaty member-states, to create more favorable conditions for a systematic long-term activity aimed at the annexation of that Socialist state by the GFR." Gomulka, op. cit., p. 315-324.

23 Ibid., p. 379.

24 Ibid., p. 388.

25 Gomulka, op. cit., p. 388.

26 A. Ross Johnson, "A New Phase in Polish-West German relations: Part III: A Preliminary Analysis", Radio Free Europe Research, Poland/ 17, August 14, 1969, p. 8.

27 Ibid.

28 Ibid., p. 9. 
29 The occasion was a visit by the Romanian President to Warsaw. For a full text of the May speech, see Gomulka, op. cit., p. 391 - 405. 30 As to Bonn's renunciation of nuclear weapons, there was Bonn's signature to the Non-Proliferation Treaty. Bonn's declaration of the Munich Agreement as invalid ad initio was not mentioned at all.

31 The formula was to provide the recognition or respecting of the Oder-Neisse frontier pending a settlement through a peace treaty. 32 The "Zgorzelec formula" in the Polish-East German treaty of June 6, 1950, omits the term "recognition" and refers only to the "established and existing" frontier, see, Whetten, op. cit., p. 155.

33 Five years had passed since Foreign Minister Rapacki made a proposal to convene an all-European Conference on December 14, 1964. 34 Gomulka, op. cit., p. 396.

35 Ibia.

36 It is important to note that when Romania established diplomatic relations with the FRG in January, 1967, Bucharest justified its policy claiming that the move was in line with the Bucharest Declaration of July 1966 and a contribution to European security. (see note 44; Chap. 2).

37 Johnson, op. cit., p. 12.

38 Polish economy in the $60^{\prime}$ s and economic reforms discussed during the Fifth Congress are well analyzed by Michael Gramarnikow, "The Polish Economy in Transition", Problems of Communism, January February 1970, (p. 40-47).

39 Nicholas Bethell, Gomulka: His Poland and His Cormunism, (Middlesex, England: Penguin Books, 1972) p. 270. 


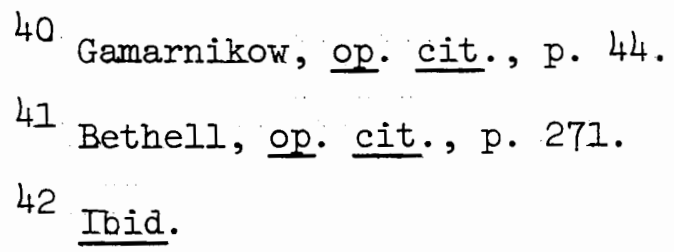

Dr. Bietz had served in the economic administration of occupied Poland during W.W. II. He was one of the few Germans who gained a certain respect from the Poles and to establish good relations with some of them. Now he not only had a particular concern for the future of Germany's relations with Poland, but, as the man who ran Krupp, was one of the few people in the Federal Republic who also had the power to offer something concrete to the Poles. It was largely on his initiative that the first "functional" (economic) contacts were made between the two countries. See Philip Windsor, Germany and the Management of Detente (Iondon: Chatto \& Windus, 1971) p. 52.

43 Poland had shown an ambivalent attitude toward the CMEA and bloc planning on the grounds that it could have perpetuated a situation in which certain countries stagnated while others went ahead. But its pressure for the reform and increasing power of the CMEA seemed to have grown at the same time as East Germany expanded economically. Thus, Foland had expected to gain economic support through both its bilateral ties with the GDR and an expanded CMEA. It seems that Warsaw-Pankow solidarity on the international scenes had developed parallel to this economic relation between the two countries. For this view, see Windsor, op. cit., p. 112. 44 Wolfgang Klaiber, "Security Priorities in Eastern Europe", Problems of Communism, May-June 1970, (p. 32-44), p. 42. 45 Johnson, op. cit., p. 15. 
46 The GDR had through this special relationship with west Germany, and in particular through the EEC agreement not to consider trade with East Germany as trade with a third country, Iong enjoyed a degree of Western subsidy and a better access to the markets of the EEC than any other East European country. For more details on this, see Windsor, op. cit., p. $115-117$.

47 Johnson, op. cit., p. 15.

48 See Gorgey, op. cit., p. 31-40, also note 11 of this Chapter. 49 The complex March event and the emergence in the Party leadership of the "pragmatists" -- younger, better-educated men largely uninvolved in the factional battles of the late 1950's and the early 1960 's, were well analysed by $\hat{A}$. Ross Johnson, "Poland: End of an Era?", Problems of Communism, January-February 1970, (p. 28-40), and also his The Polish Riots and Gomulka's Fall, the RAND Corporation, P.4615, April 1971. These young pragmatists influenced the major policy departure which was more realistic and more Polish-centered (as opposed to slavishly pro-Soviet or pro-GDR) approach to the German problem.

50 See note 20 of this Chapter.

51 See note 11 of this Chapter.

52 Bethell, op. cit., p. 272.

53 Ibid.

54 Johnson, "A New Phase in Polish-West German relations", op. cit., p. 17 .

\section{Ibid.}

56 Bromke, op. cit., p. 124. 
57 Johnson, "A New Phase in Polish-West German relations", op. cit., p. 10

58 Tbid.

59 A. Ross Johnson, The Warsaw Pact's Campaign for "European Security", (Santa Monica, CA: The RAND Corporation R-565-PR, 1970), p. $32-35$.

60 Adam Bromke, "Poland under Gierek- A New Political Style", Problems of Communism, September - October 1972, (p.1 - 19), p. 8-9.

61 Bromke, Poland: The Last Decade, op. cit., p. $49-51$.

62 Ibia.

63 Ibid.

64 Polish Institute on International Affairs, op. cit., p. 53.

65 Bromke, "Poland under Gierek: A New Political Style", op.

cit., p. 17-18.

66 Ibid.

67 Ibid. 


\section{CONCLUSION}

The Rapacki Plan marked the commencement of postwar Polish foreign Policy. It was derived from Polish interests, but the ceiling was set by Poland's powerful Eastern neighbor. Indeed, the Rapacki Plan would have served Soviet interests in the European continent while at the same time would have eroded the Soviet influence over Poland. When the Soviets supported the Polish proposal, they justified the risks by the benefits they hoped to gain from the possible Western acceptance of the plan. But when they thought that the possible gains would not be greater than the potential risks accompanied in implementing the plan, the Soviets used it as a mere propaganda. Thus, the Rapacki Plan was the product of the diplomacy between the Poles and the Soviets.

Even though this aspect of the Rapacki Plan gradually faded away after the Soviets took a hard stand on Berlin, the Polish desire was carried by the third and the fourth variant of the plan. But the limit set by the Soviets seemed to have been the main reason for the West's non-acceptance of the Polish proposals. When West Germany emerged as an economically and militarily formidable power, the Poles began to give greater attention to their western frontier. After the Rapacki proposal for an all-European Conference, Poland concentrated its efforts on gaining the recognition of the Oder-Neisse frontier as postwar reality. To accomplish this objective, the proposed CSCE 
provided itself as a powerful vehicle.

Bonn's recognition of the Oder-Neisse boundary and the strong backup of the CSCE project finally gave Polish foreign policy greater room for maneuver. It became more self-assertive and more independent. Poland's economic and cultural ties with the West developed and its isolation seemed largely overcome. Here, one should ask how much independence the Poles expected to gain from the Soviet tutelage. Now that the borders were secured, did Poland still have to stay in the Soviet bloc?

The answer to this question should be given in light of Poland's geographic position between Germany and the Soviet Union, the existence of the Warsaw Pact, the economic integration, and the so-called Brezhnev doctrine of limited sovereignty. One should also be well aware of the fact that more and more Poles were beginning to reason along the line of this argument:

What would Poland mean in the Western alliance?... It would occupy a lowly place, after England, Germany, France, Italy in Europe and dozens of other states on a world scale... In view of the primary importance to America of Germany it would be the losing party in any Polish-German conflict...

In the socialist camp the proportions are reversed: Poland as the largest People's Democracy is third on the list of socialist states after the Soviet Union and China, and second in Europe. ${ }^{1}$

It is hard to say whether this argument was a pessimistic resignation or a sophisticated adaptation to the objective reality. But, it is clear that the argument was closer to the one of Dmowski than that of Josef Beck. Polish foreign policy chose the line envisaged by Dmowski. Even after the West German recognition of the Oder-Neisse border, the fundamental tenet of Polish foreign policy remained unchanged. 
Poland remained a vital member of the Warsaw Pact and, rather than attempting to take off from the Soviet orbit, it aimed at becoming an equal ally of the Soviet Union. It stood on the logic that the greater the role Poland played within the Pact, the more freedom it could enjoy in its foreign policy. which could in turn, help Poland gain even closer ties with the West.

1 Slowo Powszechne, March 21, 1958, cited in Brzezninski, Zbigniew K., The Soviet Bloc: Unity and Conflict, (Cambridge, Mass.: Harvard University Press, 1977, Seventh Edition, 1977), p. 365-366. 
SOURCES CONSULTED

BOOKS

Albrecht, Andrzej The Rapacki Plan - New Aspects. (Warsaw: Zachodnia Agencja Prasowa, 1963).

Andren, Nils and Birnbaum, Karl L.E. (eds.) Beyond Detente: Prospects for East-West Cooperation and Security in Europe. (Leyden: Sijthoff, 1976).

Benes, Vaclav L. and Pounds, Norman J. G. Poland. (New York: Praeger Publishers, 1970).

Bethell, Nicholas Gomulka: His Poland and His Communism. (Middlesex, England: Penguin Books, 1972).

Birnbaum, Karl E. Peace in Europe: East-West Relations 1966-1968 and the Prospects for a European Settlement. (London: Oxford University Press, 1970).

Brandt, Willy A Peace Policy for Europe. (New York: Holt, Rinehart and Wilson, 1968).

Bromke, Adam Poland's Politics: Idealism vs. Realism. (Cambridge, Mass.: Harvard University Press, 1967).

Bromke, Adam Poland: The Last Decade. (Ontario: Mosaic Press, 1981).

Bromke, Adam and John W. Strong (eds.) Gierek's Poland. (New York:

Praeger Publishers, 1973).

Brown, James F. Relations Between the Soviet Union and Its East

European Allies: A Survey. (Santa Monica, CA.: The RAND

Corporation, Nov. 75). 
Brzezinski, Zbigniew K. The Soviet Bloc: Unity and Conflict.

(Cambridge, Mass.: Harvard University Press, 1977, Seventh Printing).

Brzezinski, Zbigniew K. Alternative to Partition. (New York: McGraw -

Hill Book Company, 1965).

Dean, Robert $D$ and Robert R. King (eds.) East European Perspectives on

European Security and Cooperation. (Washington: Praeger Publishers, 1974 ).

Dziewanowski, M. K. Poland in the 20th Century. (New York: Columbia University Press, 1977).

Ferraris, Luigi Vittorio (ed.) Report on a Negotiation: HelsinkiGeneva-Helsinki 1972 - 1975. (Alphen aan den Rijn, Geneva: Sijthoff \& Noordhoff International Publishers, 1979). Gomulka, Wladyslaw On the German Problem: Articles and Speeches. (Warsaw: Ksiazka i Wiedza Publishers, 1969). Gorgey, Laszlo Bonn's Eastern Policy: 1964-1971. (New York: Archon Books, 1972).

Gribanov, M. Security for Europe: Prospects for an All-European Conference (Moscow: Novosti Press Agency Publishing House, 1972).

Griffiths, Franklyn, Lincoln P.:Bloomfield, and Walter C. Clemens, Jr. Khrushchev and the Arms Race (Cambridge, Mass.: The M.I.T. Press, 1966).

Herz, John H. The Government of Germany (New York: Harcourt Brace Jovanovich, Inc., 1972, Second Edition). 
Hiscocks, Rochard Poland: Bridge for the Abyss? (London: Oxford University Press, 1963).

Hunter, Robert Security in Europe. (Bloomington, Indiana: Indiana University Press, 1972, Second Edition).

Johnson, A. Ross The Polish Riots and Gomulka's Fall. (Santa Monica, CA.: The RAND Corporation, P-4615, April 1971).

Johnson, A. Ross The Warsaw Pact's Campaign for "European Security".

(Santa Monica, CA.: The RAND Corporation, R-565-PR, 1970). Keesing's Research Report Germany and Eastern Europe Since 1945:

From the Potsdam Agreement to Chancellor Brandt's Ostpolitik. (New York: Praeger, 1977).

King, Robert R. and James F. Brown (eds.) Eastern Europe's Uncertain

Future: A Selection of Radio Free Europe Research Reports.

(New York: Praeger Publishers, 1977).

Klafkowski, Alfons The Polish-German Frontier after W. W. II,

Edward Rothert, translator. (Poznan: Wydawnictwo Poznanskie, 1972).

Korbel, Josef Detente in Europe. (Princeton, New Jersey: Princeton University Press, 1972).

Kulski, W. W. Germany and Poland: From War to Peaceful Relations.

(New York: Syracuse University Press, 1976.)

Leslie, R. F. (ed.) The History of Poland since 1863 (London:

Cambridge University Press, 1980).

Moreton, N. Edwina East Germany and the Warsaw Alliance: The Politics of Detente. (Boulder, CO: Westview Press, 1979). 
NATO Information Service NATO: Facts and Figures (Brussels, January, 1976).

Polish Institute on International Affairs Conference on Security and Cooperation in Europe: A Polish View. (Warsaw: Polish Scientific Publishers, 1976).

Remington, Robin Alison The Warsaw Pact: Case Studies in Communist

Conflict Resolution. (Cambridge, Mass.: The M.I.T. Press, 1971)

Roos, Hans A History of Modern Poland. (London: Eyre and SPottiswoode, 1966 .

Simmonds, George W. (ed.) Nationalism in the USSR and Eastern Europe. (Detroit: The University of Detroit Press, 1977).

Stehle, Hansjakob The Independent Satellite. (New York: Praeger Publishers, 1965).

Whetten, Lawrence I. Germany's Ostpolitik: Relations between the Federal Republic and the Warsaw Pact Countries. (London: Oxford University Press, 1971).

Windsor, Philip Germany and the Management of Detente. (London: Chatta \& Wondus, 1971). 


\section{ARTICLES}

Ascherson, Neal. "Poland's Place in Europe." The World Today, December 1969, pp. 520-529.

Brandt, Willy. "German Policy toward the East." Foreign Affairs, April 1968, pp. 476-486.

Bromke, Adam. "Polish Nationalism and Communism." Foreign Affairs, July 1962 , pp. 635-643.

Bromke, Adam. "Poland under Gierek - A New Political Style." Problems of Communism, September-October 1972, pp. 1-19.

Cleveland, Harlan. "NATO after invasion." Foreign Affairs, January 1969, pp. 244-257.

Gaitskell, Hugh. "Disengagement: Why? How?" Foreign Affairs, July 1958, pp. 538-548.

Gamarnikow, Michael. "The Polish Economy in Transition." Problems of Communism, January-February 1970, pp. 40-47.

H. A. (initials only). "Changing Relationships in Eastern Europe." World Today, February 1958, pp. 54-60.

Hiscocks, Richard. "Progress East of the Oder-Neisse." World Today, November 1960 , pp. 491-500.

Jaszunski, P. "Poland and the Nonnuclear Zone." International Affairs (Moscow), April 1964, pp. 28-35.

Johnson, A. Ross. "A New Phase in Polish-West German Relations: Part III: A Preliminary Analysis." Radio Free Europe Research, Poland/ 17, August 14, 1969, pp. 1-20. 
Johnson, A. Ross. "Poland: End of an Era?" Problems of Communism, January-February $1970, \mathrm{pp} .28-40$.

Kissinger, Henry A. "Missiles and the Western Alliance." Foreign Affairs, April 1959, pp. 385-401.

Klaiber, Wolfgang. "Security Priorities in Eastern Europe." Problems of Communism, May-June 1970, pp. 32-44.

L. B. (initials only). "Revisionist Poland." World Today, June, 1958, pp. 247-259.

Lachs, Manfred. "An Atom-Free Zone in Central Europe." International Affairs Moscow, August 1959, pp. 19-23.

P. J. D. W. (initials only). "The Pursuit of Disengagement." World Today, April 1959, pp. 156-168.

Povolny, Mojmir. "The Soviet Union and European Security Conference." Orbis, Spring 1974, pp. 201-230.

Sommer, Theo. "Bonn Changes Course." Foreign Affairs, April 1967, pp. $477-491$.

Strauss, Franz Josef. "Soviet Aims and German Unity." Foreign Affairs, April 1959, pp. 366-377.

Ulam, Adam. "The USSR and Europe: The Destiny of Eastern Europe." Problems of Communism, January-February 1974 Vol. XXIII, pp. $1-12$.

Whetten, Lawrence L. "Recent Changes in East European Approaches to European Security." World Today, July 1970, pp. 277-288. 